
\title{
25 Research Square \\ Distribution of Extreme Rainfall Events and Their Environmental Controls in The West African Sahel
}

Edward K. Vizy ( $\square$ ned@jsg.utexas.edu )

The University of Texas at Austin https://orcid.org/0000-0002-5019-2819

Kerry H. Cook

The University of Texas at Austin

\section{Research Article}

Keywords: West African Sahel, extreme rainfall, mesoscale convective system (MCS), African easterly wave, intertropical front, intertropical discontinuity, dryline, vertical wind shear, flooding

Posted Date: October 21st, 2021

DOl: https://doi.org/10.21203/rs.3.rs-928479/v1

License: (1) This work is licensed under a Creative Commons Attribution 4.0 International License. Read Full License 


\section{Abstract}

West African Sahel extreme rainfall events are impactful when strong mesoscale convective systems (MCSs) produce large amounts of rainfall in short periods. NASA IMERG rainfall estimates and the ERA5 reanalysis are examined to understand where the top 100 highest $12 Z-12 Z$ 24-h rainfall totals and MCS storm genesis occur, and to assess the relative importance of environmental conditions in their generation including the influence of atmospheric moisture and vertical wind shear.

Most of the top 100 events are located south of $14^{\circ} \mathrm{N}$. Events cluster over three regions, namely, Mali, Burkina Faso, and northern Nigeria. The associated MCSs are typically not locally generated, forming instead at distances greater than $100 \mathrm{~km}$ upstream. Composites reveal that a significant increase in atmospheric moisture content occurs prior to development, but there is no evidence of significant changes in the $600-925 \mathrm{hPa}$ vertical wind shear. This indicates that vertical wind shear is less influential in extreme storm development than atmospheric moisture preconditioning.

The top 10 events are further evaluated. A change in these storms' direction and speed near the maximum rainfall location is common, suggesting the MCSs are reorganizing around peak rainfall intensity time. Three atmospheric conditions are associated with these events. They are (1) moisture preconditioning of the atmosphere, (2) interaction of the storm in the wake of a region of anticyclonic flow, and (3) interaction of the storm in the wake of a region of anticyclonic flow and the Sahel/tropical dryline boundary.

\section{Introduction}

Heavy rainfall events are a major weather hazard over the semi-arid West African Sahel. During the boreal summer, such events frequently occur when strong organized areas of convection such as mesoscale convective systems (MCSs) and West African squall lines move across sub-Saharan Northern Africa. These systems can deliver copious rainfall in often short periods resulting in flooding that impacts the health and livelihoods of the population (Tschakert et al. 2010; Anash et al. 2020). Given the likelihood that such heavy rainfall events may become more frequent and/or intense in the future (Han et al. 2019; Kendon et al. 2019; Fitzpatrick et al. 2020), and observations that suggest this intensification is underway (Taylor et al. 2017; Tramblay et al. 2020; Klein et al. 2021), there is a crucial need to better understand how these rainfall systems develop in order to improve our climate-scale predictive capabilities.

The purpose of this study is to identify rainfall systems that produce heavy rainfall events over the West African Sahel, understand where these events occur including where the associated MCSs originate, and assess the relative importance of environmental conditions including the preconditioning of moisture in the atmosphere and the vertical wind shear on storm development. Doing so will enhance our fundamental understanding about how intense rainfall events form, as well as improve our current and future predictive capabilities by pointing to the environmental factors that are most relevant. 
Background is provided in Section 2. Section 3 describes the datasets and analysis methods utilized. Results are presented in Section 4, while findings are summarized and conclusions drawn in Section 5.

\section{Background}

Heavy rainfall events and associated flooding due to inundation and runoff are acute problem throughout the world. This includes West Africa and the Sahel where extreme rainfall events lead to storm-related damage to homes/property, economic hardships due to crop and livestock losses, displacement of the population from flood-prone areas, and flood-related fatalities (Di-Baldassarre et al. 2010; Panthou et al. 2014).

Storms that deliver copious amounts of rainfall often develop quickly, providing minimal lead time to warn the population and prepare for adverse consequences (Engel et al. 2017). Flooding potential is exacerbated over urban areas where the density of buildings, roads, and pavement enhances runoff in areas where there are high population densities (Douglas et al. 2008). Since the 1980s, the frequency of these stronger, better organized rainfall producing storm systems over the West African Sahel has changed (Taylor et al. 2017), accompanied by an observed increase in storm intensity and flood damage (Giorgi et al. 2011; Panthou et al. 2014). Climate model projections (Kundzewicz et al. 2014; Han et al. 2019; Kendon et al. 2019; Fitzpatrick et al. 2020) indicate that these types of events are likely to become more frequent and/or intense under global warming. These changes in rainfall will undoubtedly lead to an increase in flood-related property damage and deaths over the West African Sahel, amplified by growing populations (Panthou et al. 2014).

Advancing our understanding of extreme rainfall events over the West African Sahel requires a basic understanding of how rainfall is delivered over the West African Sahel, particularly during the boreal summer monsoon season when most of the rainfall occurs. It is estimated that between $70-95 \%$ of the total rainfall over this region is associated with organized convective systems (Laurent et al. 1998; Laing et al. 1999; Mathon et al. 2002; Mohr 2004; Liu et al. 2019) including bowing squall lines (Eldridge 1957; Desbois et al. 1988; Peters and Tetzlaff 1988; Rowell and Milford 1993; Fink and Reiner 2003) as well as other types of organized MCSs (Laing and Fritsch 1993; Laurent et al. 1998).

Environmental factors influence the development and lifespan MCSs. Most favorable for development is a moist, conditionally unstable environment with a lifting mechanism to trigger deep convection (Doswell et al. 1996). Specific to the West African Sahel, the low-level inflow of moist, tropical flow from the Gulf of Guinea (Cook 1997; Hagos and Zhang 2010; Thorncroft et al. 2011; Cook 2015; Vizy and Cook 2018) and the development of African easterly waves (AEWs; Carlson 1969a, b; Burpee 1972; Reed et al. 1977) are conducive to development. There are two preferred storm tracks across sub-Saharan northern Africa, namely a southerly track between $8^{\circ} \mathrm{N}-15^{\circ} \mathrm{N}$, and a northerly track north of $15^{\circ} \mathrm{N}$ (Diedhiou et al. 1999; Fink and Reiner 2003; Hsieh and Cook 2005, 2008; Mekonnen et al. 2006). In the southern storm track, MCS activity tends to occur to the west of the AEW trough (Burpee 1972; Tetzlaff and Peters 1988), while in the northern storm track convection tends to occur to the to the east of the trough where there is 
enhanced southerly flow of moist air (Burpee 1972; Duvel 1990; Mathon et al. 2002; Fink and Reiner 2003). AEW disturbances perturb the mid-tropospheric horizontal shear associated with the midtropospheric African easterly jet (AEJ) as well as the vertical wind shear, both of which can be important factors for the development squall lines and MCSs (Rowell and Milford 1993; Hodges and Thorncroft 1997; Mohr and Thorncroft 2006). In particular, shear plays a crucial role in organizing convection into MCSs (Barnes and Sieckman 1984; Rotunno et al. 1988; Weisman and Rotunno 2004).

Topography is also influential in storm development and organization over the West African Sahel. Elevated terrain promotes vertical lifting of the low-level flow, and differential surface heating generates near surface convergence boundaries that can help trigger and develop convective systems during the daytime (Tetzlaff and Peters 1988; Mohr and Thorncroft 2006; Laing et al. 2008; Vondou 2012). MCSs are observed to propagate away from elevated terrain during the evening/night, bringing heavy rainfall to areas downstream away from the topographic feature (Mohr 2004; Zhang et al. 2016a, b; Vizy and Cook $2018,2019 a)$. This suggests that the diurnal cycle plays a pivotal role in storm formation and development over West Africa (Parker et al. 2005).

Smaller scale processes, such as cold pool outflow and air mass boundaries, also influence MCS development over West Africa. Cold pool outflow boundaries are formed when evaporative cooling of falling precipitation within an MCS results in a downdraft of relatively cool air that expands radially near the surface. A mesohigh is formed, with strong gust fronts that become convergence boundaries, triggering the further development of convection (Zipser 1977; Redelsperger and Lafore 1988; Marsham et al. 2013; Dione et al. 2014; Provod et al. 2016). Airmass boundaries form between the moist, tropical West African monsoon air and dry, Sahel/Saharan air across West African Sahel during the boreal summer. The moist air is shallow near the frontal boundary, deepens equatorward, and varies over the diurnal cycle (Parker et al. 2005). These frontal zones provide a capping inversion for low-level turbulence that delays the release of convective instability (Carlson et al. 1983; Trier et al. 2004, 2015). This allows for the build-up of stronger instability and the development of stronger MCSs over the Sahel (Vizy and Cook 2018, 2019a), operating in a manner similar to that of a dryline frontal boundary (Eldridge 1957). In the existing literature (e.g., Hamilton and Archbold 1945; Hastenrath and Lamb 1977; Lélé and Lamb 2010) this frontal boundary over West Africa is often referred to as the Intertropical front (ITF) or Intertropical discontinuity (ITD), but these names are not accurate since an intertropical front is technically defined as a front within the equatorial trough that separates the air of the Northern and Southern Hemisphere (American Meteorological Society 2021), and the West African Sahel lies well north $\left(12^{\circ}-20^{\circ}\right.$ of latitude) of the equator. To avoid confusion, we refer to this airmass boundary as the Sahel/tropical Africa dryline boundary.

While these factors play an important role in the development of convection over the region, it is less clear why some storms are more extreme than others. Progress on this issue has been limited over West Africa as most studies focus on individual events and/or particular regions (Tarhule 2005; Samimi et al. 2012; Magami et al. 2014; Panthou et al. 2014; Zahiri et al. 2016; Anash et al. 2020). For example, Knippertz and Martin (2005) evaluated 3 cold season extreme rainfall events over West Africa and found that 
tropical-extratropical interactions led to a plume of moisture over West Africa that plays an important role in development. Engel et al. (2017) examined two high-impact heavy rainfall events over urban areas, namely, Ouagadougou on 1 September 2009 and Dakar on 26 August 2012. Unusual synoptic-convective dynamic developments led to the exceptional rainfall totals for both events. The Ouagadougou event was associated with AEW breaking (Galvin 2010; Cornforth et al. 2017) that resulted in two strong MCSs passing over the city within 6 hours.

Schlueter et al. (2019a, b) develop a broader understanding of storm systems over the region by evaluating the relationship between rainfall and six wave types over sub-Saharan northern Africa. The six types are eastward intertial-gravity waves, AEWs/tropical disturbances, Kelvin waves, mixed Rossbygravity waves, equatorial Rossby waves, and Madden-Julian oscillation (MJO) waves, and they operate on timescales ranging from sub-diurnal to intraseasonal timescales. The constructive and destructive interactions among the waves offer some promise in explaining the development of extreme convective events over West Africa. Slower moving waves such as the MJO and equatorial Rossby waves primarily impact precipitable water, while faster AEWs, Kelvin waves, and mixed-Rossby gravity waves primarily modulate moisture convergence over West Africa and the Sahel. This is consistent with prior studies (Matthews 2004; Janicot et al. 2009, 2011; Leroux and Hall 2009; Alaka Jr and Maloney 2012, 2014) that indicate the MJO can have a significant remote influence on convection over West Africa during boreal summer.

There is a need to further improve our fundamental understanding of the development of extreme rainfall events over the West African Sahel. In this study we contribute by examining the development of the systems that deliver the heaviest 24-h rainfall total over a broad region of the West African Sahel.

\section{Datasets And Methodology}

\section{1 Datasets}

High spatial resolution datasets at timescales most relevant for storm development (e.g., 1 hour or less) are needed to identify heavy rainfall events and understand the environmental conditions associated with their development. For rainfall, we utilize the NASA Long-term Integrated Multi-satellitE Retrievals for global precipitation measurement Version 06B (IMERG; Hou et al. 2014; Huffman et al. 2020). This 0.10 resolution product yields rainfall estimates between $60^{\circ} \mathrm{N}-60^{\circ} \mathrm{S}$ by fusing measurements from the Global Precipitation Measurement (GPM) satellites (2014 - present) with estimates from the Tropical Rainfall Measuring Mission (TRMM) satellites (2000 - 2014). IMERG provides 30-minute rainfall estimates over the past 20 years which is sufficient for identifying extreme rainfall events. While IMERG provides a variety of rainfall estimates, we use the calibrated rainfall product for this study because it is thought to provide a reasonable estimate (Dezfuli et al. 2017; Maranan et al. 2020; Tapiador et al. 2020).

Additional data sources are examined to ground-truth heavy rainfall events identified from IMERG. This is necessary because there is uncertainty in estimating rainfall from satellite measurements as processing algorithms make assumptions regarding a variety of issues such as temperature profiles and 
droplet sizes, and filling in for limited spatio-temporal coverage can affect the final rainfall estimate (Kidd and Levizzani 2011; Pfeifroth et al. 2013, 2016). For regions with reliable and comprehensive rain-gauge networks, the most effective method of validation is to cross-reference satellite precipitation estimates with available ground truth gauge measurements (Nair et al. 2009; Gaona et al. 2016; Watters et al. 2018). This is a less viable option over the West African Sahel, where ground-based measurement networks are more limited (Nicholson et al. 2003; Roca et al. 2010; Dezfuli et al. 2017; Maranan et al. 2020). To provide some level of ground-truth confirmation, events identified in IMERG are crossreferenced with impact-driven information from the Centre for Research on Epidemiology of Disasters (CRED) Emergency Events database (EM-DAT; EM-DAT 2020), the Famine Early Warning Systems Network (FEWS NET) weekly weather hazards for Africa summaries (FEWS NET 2020), the United Nations Office for the Coordination of Humanitarian Affairs (OCHA) Reliefweb reports, International Federation of Red Cross and Red Crescent Societies Disaster Relief Emergency Fund (DREF) bulletins, and independent published articles.

The ECMWF ERA5 reanalysis (ERA5, C3S 2017) is analyzed to relate the heavy rainfall events to the larger-scale environmental conditions. ERA5 is a $5^{\text {th }}$ generation product that provides global $0.25^{\circ}$ resolution hourly gridded output of atmospheric and surface fields from 1979 - present. The finer spatial and temporal resolutions of ERA5 make it a reasonable data source to understand environmental conditions at sub-diurnal timescales (Danso et al. 2019; Vizy and Cook 2019b; Li et al. 2020).

\subsection{Methodology}

IMERG rainfall estimates are used to identify the wettest 24-h rainfall events over the West African Sahel between $2000-2019$. Here, the West African Sahel is defined as the area from $8.05^{\circ} \mathrm{W}-12.95^{\circ} \mathrm{E}$ and $12.05^{\circ} \mathrm{N}-17.95^{\circ} \mathrm{N}$, as shown in Fig. 1. These bounds are set to avoid prominent terrain features including the Jos Plateau of Nigeria to the south $\left(9^{\circ} \mathrm{N} ; 9^{\circ} \mathrm{E}\right)$, the Guinean Highlands $\left(8^{\circ} \mathrm{N} ; 10^{\circ} \mathrm{W}\right)$ to the southwest, the Aïr Mountains of Niger to the north $\left(18^{\circ} \mathrm{N} ; 9^{\circ} \mathrm{E}\right)$, and Lake Chad to the east $\left(13^{\circ} \mathrm{N} ; 14^{\circ} \mathrm{E}\right)$.

While some heavy rainfall events last for multiple days and are associated with several rounds of convective activity, our focus is on shorter, sub-diurnal rainfall events associated with the development of MCSs. This includes African squall lines which are known to frequently occur during the boreal summer. We apply a $12 Z-12 Z$ 24-h window and use it to identify the dates and location of the largest 24-h rainfall events in the region. The $12 Z-12 Z$ time window aligns with our the typical MCS lifecycle over the Sahel. In many, but certainly not all, instances over the West African Sahel, MCSs are more likely to develop in the afternoon shortly after peak daytime heating, often persisting and in some instances intensifying during the evening/night hours before weakening the following morning. Our results may have some dependence on this time window.

To determine the events that produce the top 100 wettest 24-h rainfall totals, we calculate the $12 Z-12 Z$ accumulated total rainfall for every day from 2000 - 2019 for each grid point in the defined analysis region. The grid point totals are then ranked from highest to lowest to find the top 100 wettest 
independent events. To identify independent events, a grid point under consideration cannot be associated with a rainfall event that has already been identified as having a higher 24-h rainfall total on the same day within $500 \mathrm{~km}$ distance of this location. This criterion is necessary because heavy rainfall events are likely to impact a spatial area greater than the size of a single grid point. Thus, the top 100 events are identified by their location and date, and as it turns out each event occurs on a different date from the other top 100 events.

The top 100 events are analyzed to evaluate where the extreme rainfall events occur based on the maximum $12 Z$ - $12 Z$ 24-h total precipitation location and where the MCS primarily responsible for the extreme event originated. The monthly occurrence distribution and the area of the daily total accumulated precipitation associated with each event for various rainfall thresholds is quantified. Compositing is used to evaluate changes in important environmental conditions for storm development including precipitable water and vertical wind shear. Composites are formed by averaging the desired field over the 100 events at the same time of day in the diurnal cycle, and composite anomalies are calculated by subtracting the top 100 composite from a weighted climatological mean value determined by the months for which the events occur. Weighting is necessary because the top 100 events occur with different frequency over the boreal warm season of May - October. Here, monthly climatological monthly mean values are assigned a weight of 1/100 May, 3/100 June, 24/100 July, 59/100 August, 9/100 September, and 4/100 October, and added together to obtain the weighted climatological value.

To evaluate storm trajectories and the sizes of the rainfall shield and the convective core for the top 10 events, we have adapted the approach of Vizy and Cook $(2018,2019 a)$ to track MCSs. A threshold rainfall rate of $100 \mathrm{~mm}$ day $^{-1}$ is used to defined the storm's rain shield at any given time. This rainfall rate threshold is selected to provide an estimate for the more intense convective core of the system where the largest percentage of the rainfall is likely to fall from for the event. Following Vizy and Cook (2018, 2019a), we assume that the convective core rain shield is at least $2000 \mathrm{~km}^{2}$ in size, in this case 16 or more contiguous grid points meeting the threshold rainfall rate value. The centroid of the above-defined rain shield is determined to define the storm's location at a given time. Then starting at the time of the peak rainfall intensity, the storm is objectively tracked forward and backward in time until either the 100 $\mathrm{mm}$ day $^{-1}$ rainfall shield no longer meets the $2000 \mathrm{~km}^{2}$ size criterion, or the storm can no longer be tracked due to merging or splitting of the storm's convective core rain shield. Additionally, the size of the storm areal extent is also evaluated for the identified storm throughout its development. This involves evaluating the size of the $5 \mathrm{~mm}_{\text {day }}{ }^{-1}$ and the $500 \mathrm{~mm}_{\text {day }}{ }^{-1}$ rainfall shields with the former threshold selected to represent the entire system including areas associated with stratiform rainfall, while the later threshold selected to represent the most intense convective core of the system. Finally, relevant atmospheric conditions from ERA5 are examined from the top 10 cases.

\section{Results}

\subsection{Events with the highest rainfall totals: The top 100}


Figure 1 a shows the location of the top $10012 Z$ - $12 Z$ 24-h maximum rainfall rate events for the analysis region, while Table 1 provides information for each event. Top 100 events occur infrequently over the northern Sahel within the analysis region, with the vast majority occurring south of $14^{\circ} \mathrm{N}$. There are 3 regions where events cluster over the southern Sahel. They are over southwestern Mali $\left(\sim 11^{\circ} \mathrm{N}\right.$, $8^{\circ} \mathrm{W} ; 24$ events), central Burkina Faso $\left(\sim 13^{\circ} \mathrm{N}, 2^{\circ} \mathrm{W} ; 10\right.$ events), and north-central Nigeria $\left(\sim 12^{\circ} \mathrm{N}, 8^{\circ} \mathrm{E} ; 17\right.$ events). Each of these regions has a strong connection with topography. Most events over Mali occur on the eastern slopes of the Mandingue Plateau, over Burkina Faso in close proximity to the North Mossi Plateau, and over north-central Nigeria to the northern slopes of the Jos Plateau. Elevation changes associated with these topographic features are modest, usually only $200-400$ meters, compared to other regional features such as the Aïr Mountains of northern Niger $\left(18^{\circ} \mathrm{N}, 9^{\circ} \mathrm{E}\right)$ and the Cameroon Highlands $\left(6^{\circ} \mathrm{N}, 11^{\circ} \mathrm{E}\right)$. However, they are apparently large enough to consistently trigger heavy rainfall amounts. For the 9 most intense events, with rainfall totals greater than $200 \mathrm{~mm}, 8$ occur south of $14^{\circ} \mathrm{N}$. The one event north of $14^{\circ} \mathrm{N}$ occurred southeast of the Airr Mountains of north-central Niger in the Damergou Gap, and it is the highest maximum total 24 -h event identified in this study.

The MCSs associated with the top 100 rainfall events are back-tracked to find their genesis locations, shown in Fig. 1b. $94 \%$ originate between $10^{\circ} \mathrm{N}$ and $20^{\circ} \mathrm{N}$. The longitudinal distribution is more uniform, with 29 generated west of $0^{\circ} \mathrm{E}, 35$ between $0^{\circ} \mathrm{E}-10^{\circ} \mathrm{E}, 17$ between $10^{\circ} \mathrm{E}-15^{\circ} \mathrm{E}$, and 19 east of $15^{\circ} \mathrm{E}$ primarily over central and southern Chad and the Darfur Mountains of the Sudan. Thus, the distance between the genesis region and the location of maximum rainfall (Fig. 1a) can be large. Only 25 of the 100 events form locally, defined here as when storm genesis occurs within $100 \mathrm{~km}$ of the maximum 24-h rainfall location. Of the other 75 events, 44 form between $100-1000 \mathrm{~km}$ away from the maximum rainfall location, 24 form 1000 - $2000 \mathrm{~km}$ away, and 7 form over $2000 \mathrm{~km}$ away.

While topography is known to be associated with MCS generation, less than half of the 100 selected storms original over orographic features, including the Ahaggar Mountains of southern Algeria (3 storms), the Airr Mountains of Niger (7 storms), and the Marra Mountains in the Darfur region of Sudan (8 storms). The most active storm genesis location is in the Lake Chad depression where 15 of the top 100 events originate (Fig. 1b). Whether and how Lake Chad contributes to storm development is under investigation in a separate study (Zhao et al. 2022).

In regards to the three event cluster regions mentioned earlier, for the 24 Mali event genesis locations, 5 form locally within $100 \mathrm{~km}$ of the maximum location, 10 form to the east over Burkina Faso, while the remaining 9 form more remotely at distances greater than $900 \mathrm{~km}$ from the Mandingue Plateau of Mali. For the Burkina Faso events over the North Mossi Plateau, 1 event forms locally while 3 originate to the north and east over the Ahaggar and Airr Mountains. The remaining 6 events have origins east of Burkina Faso, primarily over the Jos Plateau region of Nigeria. For the north-central Nigeria events, 3 form locally, while 3 form east of $20^{\circ} \mathrm{E}$. Most of the MCSs associated with extreme rainfall events over this region (11 events) originate in the vicinity of Lake Chad. 
Table 1 also provides information on the duration and maximum rainfall intensity of each event. Seven of the longer events, that is, events that exceed 1 standard deviation over the mean, are among the 25 events with highest rainfall, with 4 in the top 10. In contrast, only 2 of the shorter duration events are among the top 25, and none are among the top 10. For peak rainfall intensity, 6 of the highest maximum intensity events are in the top 25, including 3 among the top 10. Conversely, only 2 of the lower peak intensity are in the top 25 , and both are long duration events.

Figure 2a shows how rainfall totals are distributed for the top 100 events listed in Table 1 . The wettest has a maximum of $291 \mathrm{~mm}$ with totals decreasing exponentially, falling below $200 \mathrm{~mm}$ by event 10,175 $\mathrm{mm}$ by event 26 , and $150 \mathrm{~mm}$ by event 78 . It is 7.5 times more likely to have a maximum rainfall total between $150-200 \mathrm{~mm}$ than greater than $200 \mathrm{~mm}$.

Figure $2 \mathrm{~b}$ displays the seasonality of the top 100 events occur. 83 of the 100 events occur during the peak of the summer monsoon season, with 24 in July and 59 in August. There are only a few events in May, June, September, and October, and none from November to April.

Figure 3 shows the 24-h areal size of the top 100 events for various rainfall total thresholds. The bars are color coded to indicate event rainfall totals at $25 \mathrm{~mm}$ intervals from $100 \mathrm{~mm}-200 \mathrm{~mm}$. The majority of the top 100 events deliver 24-h rainfall totals exceeding $100 \mathrm{~mm}$ over an area of around $4000 \mathrm{~km}^{2}$ or less. The heavy-rain (>100 mm) areas of 12 of the top 100 events are greater than $20,000 \mathrm{~km}^{2}$, with 6 of these events ranked in the top 10 (Table 1). This indicates that the highest 24 -h precipitation totals, that is, the events that lie on the steepest part of the distribution curve shown in Fig. 2a, are more likely to have a larger areal coverage.

Composites formed from the top 100 events are compared with climatological conditions to better understand the environmental conditions associated with these extreme cases. Fig. 4a shows the climatological precipitable water and low-level $925 \mathrm{hPa}$ winds at 12Z, while Fig.4b shows the composite anomalies. Climatologically, precipitable water is greater than $45 \mathrm{~mm}$ south of $14^{\circ} \mathrm{N}$, indicative of the deep moist tropical air that is typically transported into West Africa via the low-level southwesterly monsoon flow during the boreal summer. North of $14^{\circ} \mathrm{N}$ precipitable water decreases to about $30 \mathrm{~mm}$ by $20^{\circ} \mathrm{N}$, reflective of the intrusion of drier, Saharan air into the northern Sahel. Most of the extreme events (Fig. 1a) occur where the climatological precipitable water is greater than $40 \mathrm{~mm}$.

Extreme events are associated with a significant and widespread increase in precipitable water over the entire Sahel (Fig. 4b). In the analysis region, precipitable water is greater by $1-3 \mathrm{~mm}$ during these events, and even more so over the northern Chad Bodélé ( $>4 \mathrm{~mm}$ ) upstream of the analysis region. The increase over Chad is associated with a significant increase in the low-level southwesterly flow into the Bodélé. There is also a significant change in the low-level flow in the analysis region over Burkina Faso. Here the anomalous low-level flow is primarily zonal, indicating a more westerly low-level monsoon flow over Burkina Faso and from Ghana to Nigeria. 
Fig. 4c shows the climatological $12 \mathrm{Z}$ wind difference between 600 - $925 \mathrm{hPa}$. There is strong zonal vertical wind shear over the West African Sahel with magnitudes greater than $14 \mathrm{~m} \mathrm{~s}^{-1}$ extending from the Senegal coast eastward to Chad. The anomalies at $12 Z$ (Fig. 4d) indicate that, outside of a few isolated areas including the Bodélé of Chad and Côte d'Ivoire, pronounced differences in vertical wind shear are not associated with extreme rainfall totals in the composite. This result is independent of the compositing hour selected, as the $12 \mathrm{Z}$ anomaly pattern in Fig. $4 \mathrm{~d}$ is consistent with those at other hours (not shown). Examination of the individual events comprising the composite indicates that the wind shear strength is anomalously weak in 46 events and anomalously strong in 54 events. (see last column of Table 1). If composites are formed individually using only events from one cluster area, namely, the Mali, Burkina Faso, and Nigeria region clusters, the conclusion is the same.

We conclude that extreme rainfall events in the analysis region are associated with a robust and significant increase in the atmospheric moisture content, not only over the region but over the entire Sahel. We do not find a connection to vertical wind shear.

\subsection{Events with the most extreme rainfall totals: The top 10}

A sub-sample of the top 100 population, namely, the 10 events that deliver the highest rainfall totals see Table 1) are next examined to gain a better understanding about the development of these storms, and extreme storms in general over the West African Sahel. Figure 5 shows the distribution of 24-h accumulated precipitation greater than $50 \mathrm{~mm}$ for each of these events. The red circles denote the location of the maximum rainfall for each case. There is no obvious similarity among the events, and they range from localized events (CASE01 and CASE08) to widespread events (CASE02 and CASE06).

Figure 5 also speaks to the potential impact of each event, especially in terms of flooding potential due to the total amount of accumulated precipitation over the 24-h period. For example, CASE01 which is associated with the highest maximum 24-h rainfall total (Table 1), has a limited are of heavy rain over central Niger with a more widespread area of $50-100 \mathrm{~mm}$ of rainfall extending from central Niger into northern Nigeria. Thus, it could be inferred from Fig. 5a that flash flooding for this case would be more likely localized over central Niger. In contrast, CASE02 and CASE07 are associated with widespread 24-h rainfall totals exceeding $150 \mathrm{~mm}$ over the Niger River basin in southern Mali that likely not only impact communities and cities including Bamako immediately after the event, but also the downstream Niger River communities in the days that follow.

FEWSNET reports, CRED EM-DAT disaster reports, OCHA Reliefweb, and DREF bulletin reports along with any available extreme rainfall studies are examined to attempt to confirm via ground-truth the impacts of the top 10 events. Results are summarized in Table 2, and indicate that 5 of the events (CASE01, CASE03, CASE04, CASE06, and CASE08) are directly associated with impactful flooding. For CASE02, CASE05, CASE07, and CASE09, available reports are vague on the exact timing of the flooding, and/or reports suggest that multiple events over many days led to the flooding. For CASE10, no ground-truth 
evidence is found, so it is unclear how impactful it is. Overall, the ground-truth results are encouraging, and give us confidence that we have identified impactful rainfall events.

Fig. 6 shows the diurnal time series of rainfall for the maximum 24-h total precipitation location (the red circles in Fig. 5) for the top 10 events. The gray lines in each panel denote the time of the maximum rainfall rate intensity for each event. Event types range from relatively shorter duration/higher peak rainfall intensity cases such as CASE01, CASE04, CASE08, and CASE10, to longer duration/weaker peak rainfall intensity cases such as CASE02, CASE03, CASE06, and CASE09. Longer duration/weaker peak intensity events occur primarily after $00 Z$, while the shorter duration/higher peak intensity events tend to occur in the late afternoon and evening.

To put into context how representative the above findings are for the larger population, all 100 events are also categorized by diurnal cycle. We calculate the mean and standard deviation for event duration and event peak intensity (Table 1), then select cases in which both the duration and peak intensity fall outside the \pm 0.5 standard deviation level. This yields a list of events for the two diurnal types as well as the opposite categories, namely the longer duration/higher peak intensity and shorter duration/ weaker peak intensity events (Table 3). We find that there are 14 longer duration/weaker peak intensity and 14 shorter duration/ higher peak intensity events out of the top 100 cases. These types are approximately 3 times more likely to occur than the longer duration/higher peak intensity and shorter duration/weaker peak intensity types. Furthermore, the selected longer duration/weaker peak intensity events yield a larger 100 $\mathrm{mm}$ rain shield area (Fig. 3) and 7 are associated with an area greater than 10,000 $\mathrm{km}^{2}$ compared to 1 event at this size for the shorter duration/higher peak intensity type.

Fig. 7a shows the diurnal cycles of rainfall for the 14 longer duration/weaker peak intensity events (gray lines) listed in Table 3 along with the composite means (red line), while Fig. $7 \mathrm{~b}$ shows their locations. While rainfall occurs prior to $00 Z$ in some events, there is a clear preference for peak rainfall rates between $00 Z$ to $03 Z$. 11 events (78\%) occur over Burkina Faso and Mali and the remaining 3 events occur north of the Jos Plateau of Nigeria.

Fig. 7c shows the diurnal cycle of rainfall for the 14 shorter duration/higher peak intensity cases. The time of peak rainfall intensity is more variable for this type, so the composite mean is relatively constant over the diurnal cycle. Event locations (Fig. 7d) are evenly distributed longitudinally, with 6 cases east of $2^{\circ} \mathrm{E}$ and 8 cases west of $2^{\circ} \mathrm{E}$. There is no clear association between the timing of peak rainfall intensity and the location for these events.

In summary, this analysis confirms that the top 10 events are representative of the top 100 population. This gives us confidence that the results focused on the top 10 events are applicable not only to the individual storms being analyzed, but also to a more robust population of storms.

Figure 8 shows the trajectories of the convective cores for the 10 events prior to (green) and following (blue) the time of peak rainfall intensity. As mentioned in section 3 the convective core is defined using a relatively high rainfall rate threshold $\left(100 \mathrm{~mm} \mathrm{day}^{-1}\right)$. Rain shields of this magnitude vary in duration 
among the cases, so some trajectories in Fig. 8 have more points than other events. For example, CASE03 (Fig. 8C), CASE06 (Fig. 8f), and CASE09 (Fig. 8i) have relatively few tracking points and they tend to be spaced closer together indicating a shorter lived and slower moving convective core for these longer duration/ weaker peak intensity events. For CASE01 (Fig. 8a), CASE04 (Fig. 8d), and CASE10 (Fig. 8j) there are more tracking points covering a larger area, indicating the strong convective core is longer lasting and, in most cases, faster moving for the shorter duration/ higher peak intensity events. However, not all events conform to this characterization. For example, CASE02 is a long duration/weak peak intensity type, but the convective core is relatively long lasting and covers a large area. Likewise, CASE08 is a short duration/high peak intensity type, but the convective core is shorter lived as the storm is more limited in size compared to other top 10 events (Fig. 3).

Fig. 8 indicates that some storms change direction when the storm is in close proximity to the location of maximum rainfall rate (red circle). Examples include CASE01 (southwesterly to a south-southwesterly track shift), CASE05 (west-southwesterly to a southwesterly track shift), and CASE10 (west-southwesterly to a south-southwesterly track shift). The physical processes responsible for directional change could be influential in producing heavy rainfall totals for some events, for example, through a reorganization in the convection in response to environmental condition changes. Future work can explore this possibility and the implications for storm intensification.

One way to understand how a storm reorganizes over time is to examine how the physical size of the storm and the size of the convective core change. Fig. 9 shows the timing of the storm rain shield area development for each case. Two areas are shown. One, denoted by the black line, is the size of the rain shield defined by the $5 \mathrm{~mm}$ day ${ }^{-1}$ rainfall rate threshold. This represents an estimate of the area of the entire MCS that includes the convective and stratiform components of the system. The other area, indicated by the blue line, is an estimate of the intense convective core. It is defined by the $500 \mathrm{~mm}_{\text {day }}{ }^{-1}$ rainfall rate threshold. The gray line denotes the time of peak rainfall rate at the storm's most intense location.

Fig. 9 indicates that events range in size from generally less than 200,000 km² (CASE03, CASE08, and CASE09), to mid-size between 200,000 - 400,000 km² (CASE01, CASE04, CASE05, and CASE10), to greater than $400,000 \mathrm{~km}^{2}$ (CASE02, CASE06, and CASE07). No apparent relationship is found between the areal size of the MCS rain shield and the longer duration/weaker peak intensity events as two cases are relatively large in size (CASE02 and CASE06), and two events are small in size (CASE03 and CASE09). In contrast, 3 of the 4 shorter duration/higher peak intensity events are mid-sized (CASE01, CASE04, and CASE10), while the fourth case, CASE07, eventually exceeds $400,000 \mathrm{~km}^{2}$.

The convective cores range in size from less than $10,000 \mathrm{~km}^{2}$ for CASE01, CASE03, CASE08, CASE09, and CASE10, to over $20,000 \mathrm{~km}^{2}$ for CASE02, CASE04, CASE05, and CASE06. When peak rainfall intensity occurs, there is a relative peak in the size of the convective core for most cases. This indicates that the convective core grows in size around the time of peak intensity. In most instances, when the intense convective core size is growing, the MCS temporarily contracts in size. In some cases, such as 
CASE01 (Fig. 10a), CASE02 (Fig. 10b), and CASE06 (Fig. 10f), this happens multiple times over the storm's lifespan, signifying a potential cycle of convective core growth and decay that is generally opposite that of the larger MCS system. Furthermore, the most intense rainfall rate does not necessarily correspond to when the convective core size is largest.

\subsection{Environmental conditions associated with the top 10 heavy rainfall events}

Figure 10a shows ERA5 $700 \mathrm{hPa}$ geopotential height, $700 \mathrm{hPa}$ wind, and precipitable water anomalies, while Fig. 10b shows the anomalous vertical wind shear for CASE01 for a representative time prior to the peak rainfall intensity. A strong mid-level disturbance was positioned east of the maximum rainfall location along the Niger/Chad border prior to the CASE01 rainfall maximum. Anomalous cyclonic flow enhanced atmospheric moisture loading over the central Sahel in support of the high rainfall totals over eastern Niger. There is a concentrated core of anomalously high meridional vertical shear, exceeding than $12 \mathrm{~m} \mathrm{~s}^{-1}$ extending northward to northern Niger, that is associated with the flow around the disturbance. South of $15^{\circ} \mathrm{N}$ there is a broad region of anomalously weak zonal shear associated with a weakening of the mid-level easterly flow.

CASE04 (Figs. 10c and d) and CASE08 (Fig. 10e and f) have different synoptic conditions and anomalous vertical wind shear patterns. Both occur over north-central Nigeria with mid-level anomalous circulation that is weaker than for CASE01, with a disturbance to the east near $15^{\circ} \mathrm{N}$ and $20^{\circ} \mathrm{E}$. The environment is anomalously wet in the vicinity and upstream of the disturbance, with precipitable water anomalies $5-10 \mathrm{~mm}$ greater than normal. This loading of atmospheric moisture content is much less than the $20-25 \mathrm{~mm}$ observed for CASE01. Vertical wind shear is only modestly stronger for these cases, generally less than $3 \mathrm{~m} \mathrm{~s}^{-1}$, and confined to a narrow region along the Niger/Nigeria border. More influential for these two cases is the close proximity of the Sahel/tropical Africa dryline boundary denoted by the red-dashed line. Mid-level flow is anticyclonic over Niger and relatively drier Sahelian air extends equatorward into southern Niger, setting up a scenario with enhanced low-level convergence south of the dryline frontal boundary over northern Nigeria. The importance of the dryline for the development of convection in this region is consistent with results from other studies (Vizy and Cook 2018, 2019a).

CASE10 (Fig. 10g and $\mathrm{h}$ ) is associated with two mid-level disturbances near southwestern Mali. The first is centered at $4^{\circ} \mathrm{W}$ and $11^{\circ} \mathrm{N}$. It lies in the southern African wave storm track, with cyclonic flow that enhances the atmospheric moisture transport over southern and western Burkina Faso. The second disturbance is stronger and located west of the first disturbance at $6^{\circ} \mathrm{W}$ and $20^{\circ} \mathrm{N}$ in the northern African wave storm track. Cyclonic flow associated with this disturbance promotes increased equatorward flow of dry western Sahel air ahead of the trailing disturbance, shifting the dryline frontal boundary southward closer to $15^{\circ} \mathrm{N}$ while enhancing the vertical zonal wind shear westward to the coast by up to $10 \mathrm{~m} \mathrm{~s}^{-1}$. Combined, these two disturbances enhance the low to mid-level convergence over southwestern Mali.

Hovmöller plots of the $700 \mathrm{hPa}$ relative vorticity and precipitable water anomalies averaged between $10^{\circ} \mathrm{N}-15^{\circ} \mathrm{N}$ for the 4 cases are shown in Fig. 11. The circles in each panel denote the longitudinal 
position and time of the peak rainfall intensity at the maximum rainfall site. Propagation speeds estimated from the $700 \mathrm{hPa}$ relative vorticity plots for relevant disturbances are noted.

CASE01 (Fig. 11a) is associated with a relatively slow-moving disturbance $\left(5.5 \mathrm{~m} \mathrm{~s}^{-1}\right)$ that is trailing a faster moving disturbance $\left(9.5 \mathrm{~m} \mathrm{~s}^{-1}\right)$. While the anomalous precipitable water (Fig. 11b) is primarily high in the 10-day window shown, the first disturbance is influential in further increases in the atmospheric moisture.

CASE04 (Fig. 11c) is also associated with two disturbances, but there is more time between the passage of these systems and both disturbances are propagating faster compared to CASE01. The maximum rainfall site occurs west of the second disturbance when the anticyclonic flow is transitioning to cyclonic flow and the atmospheric moisture content begins to increase (Fig. 11d).

CASE08 (Fig. 11e) is associated with a disturbance propagating at $7.1 \mathrm{~m} \mathrm{~s}^{-1}$. While the peak rainfall intensity occurs when the circulation is only starting to become cyclonic, the environment is relatively moist even when the flow is slightly anticyclonic between 18 - 21 July 2001 (Fig. 11f).

Finally, CASE14 is associated with a weak disturbance that originates on 17 July 2004 around $15^{\circ} \mathrm{E}$, and propagates at $9.8 \mathrm{~m} \mathrm{~s}^{-1}$ (Fig. $11 \mathrm{~g}$ ). Around the time of maximum rainfall intensity, the propagation speed slows to $3.7 \mathrm{~m} \mathrm{~s}^{-1}$ where the disturbance eventually merges into the second disturbance that forms a couple days later. This slowdown in the first disturbance occurs when the system encounters drier (Fig. 11h) anticyclonic flow over far western West Africa. It is not until the stronger, second disturbance reaches the area that the storm sheds the West African coast into the eastern North Atlantic.

Figure 12 shows ERA5 700 hPa geopotential height, wind, precipitable water, and vertical wind shear anomalies for select times of the 4 longer duration/weaker peak intensity rainfall events. CASE02 (Fig. 12a and b), CASE03 (Fig. 12c and d), and CASE06 (Fig. 12e and f) are associated with strong disturbances in the southern AEW storm track, while the disturbance for CASE09 (Fig. 12g and $h$ ) is weaker than the other three events. All three events are associated with positive precipitable water anomalies in the vicinity of the disturbance. CASE03 and CASE06 are associated with anomalous westerly/west-southwesterly flow, and CASE02 and CASE09 are associated with anomalous northwesterly flow and drier air ahead of the disturbance similar to CASE10 (Fig. 10g). The Sahel/tropical Africa dryline boundary is influential only for CASE09 due to its location farther north.

CASE02 (Fig. 12b) is associated with enhanced meridional vertical wind shear greater than $10 \mathrm{~m} \mathrm{~s}^{-1}$ ahead of the disturbance, while CASE03 (Fig. 12d) is associated with a strong negative anomaly in the vertical zonal wind shear. The locations of CASE06 (Fig. 12f) and CASE09 (Fig. 12h) are located at the boundary between anomalously strong meridional vertical shear to the west and anomalously weak zonal vertical shear to the east. The former is associated with coastal ridging that is weakening as it leaves the West African coast, while the latter is associated with changes in the low-to mid-level flow along the southern flank of the approaching disturbance 
Figure 13 shows Hovmöller plots of the $700 \mathrm{hPa}$ relative vorticity and precipitable water anomalies for the longer duration/weaker peak intensity events. CASE02 (Fig. 13a) is associated with a disturbance that slows over western West Africa, followed by a stronger disturbance propagating at $9 \mathrm{~m} \mathrm{~s}^{-1}$ a couple of days later. The anticyclonic flow is relatively dry (Fig. 13b) until the second system approaches and wrap around moisture builds over the region. CASE03 occurs in a particularly active period with multiple disturbances propagating across the Sahel (Fig. 13c) associated with an anomalously moist environment west of $10^{\circ}$ E over the 10-day period shown (Fig. 13d). The disturbance most closely associated with the event originates around $15^{\circ} \mathrm{E}$ and propagates at a speed of $7.4 \mathrm{~m} \mathrm{~s}^{-1}$ to about $4^{\circ} \mathrm{W}$ when it slows to $4.6 \mathrm{~m}$ $\mathrm{s}^{-1}$. The peak intensity of rainfall coincides with this slowdown. CASE06 is associated with two relatively strong disturbances (Fig. 13e) with the first moving faster than the second, helping to build atmospheric moisture over West Africa prior to the second system (Fig. 13f). The event is closely associated with the second disturbance which is relatively slow moving $\left(5.5 \mathrm{~m} \mathrm{~s}^{-1}\right)$. CASE09 (Fig. $13 \mathrm{~g}$ ) is associated with a short-lived disturbance that is moving westward into an environment that is primarily anticyclonic and anomalously dry (Fig. 13h). The environmental conditions associated with this case are similar to those for CASE10.

Finally, Fig. 14 shows results for CASE05 and CASE07. These two cases are associated with particularly strong disturbances with $700 \mathrm{hPa}$ geopotential height anomalies less than $-40 \mathrm{~m}$, precipitable water anomalies greater than $15 \mathrm{~mm}$, and strong vertical wind shear prior to the peak intensity (Figs. 14a - d). Ahead of the disturbances the environment is drier than normal, particularly for CASE05. The Sahel/tropical Africa dryline boundary is in close proximity to the maximum rainfall location for CASE05, but not CASE07. Figs. $14 \mathrm{e}-\mathrm{h}$ show the $700 \mathrm{hPa}$ relative vorticity and anomalous precipitable water Hovmöller plots for CASE05 and CASE07. Both are associated with fairly strong disturbances propagating westward into an anomalously dry environment, with the anticyclonic flow preceding the disturbance being stronger for CASE05 than CASE07.

Overall, a variety of factors are associated with the development of extreme rainfall events over the region. Based on the analysis of the top 10 events, three atmospheric conditions are identified here as being particularly important. They are the importance of moisture loading of the atmosphere prior to the event, interaction of the developing storm in the wake of a region of anticyclonic flow, and interaction of the storm in the wake of a region of anticyclonic flow and the Sahel/tropical Africa dryline boundary.

\section{Summary And Conclusions}

Extreme rainfall events associated with organized convective activity over the West African Sahel often resulting in flooding and adverse consequences for the population. A better understanding of the types of storms that deliver these high rainfall amounts, including the environmental conditions in which they form, is needed to improve short-term and climate-scale prediction. One hundred storms that delivered the highest 24-hour rainfall totals during the 2000-2019 period over the West African Sahel $\left(8.05^{\circ} \mathrm{W}-\right.$ $12.95^{\circ} \mathrm{E} ; 12.05^{\circ} \mathrm{N}-17.95^{\circ} \mathrm{N}$ ) are examined using NASA IMERG satellite-derived rainfall estimates and the ERA5 atmospheric reanalysis data. The preferred locations for these extreme events are identified, along 
with the regions in which the disturbances originate. We examine the mechanisms of storm intensification, including the importance of environmental conditions such as moisture preconditioning and vertical wind shear. We focus on heavy rainfall events on sub-diurnal times scales; multiple-day heavy rainfall events are not considered in this study.

Examination of the distribution curve of the top 100 maximum 24-h rainfall totals in IMERG (Fig. 2a) indicates that the wettest event having a maximum of $291 \mathrm{~mm}$, with totals decreasing exponentially, meaning that a top 100 event is 7.5 times more likely to be less than $200 \mathrm{~mm}$ rather than greater than $200 \mathrm{~mm}$. Seasonally, 83 of the top 100 events occur in July and August coinciding with the peak wet season over the Sahel with no top 100 events during November - March (Fig. 2b).

The 100 selected extreme events are unevenly distributed over the West African Sahel. They are infrequent over the northern Sahel and more common south of $14^{\circ} \mathrm{N}$ (Fig. 1a). Three regions where events cluster over the southern Sahel are identified, and each is tied to topography. They are near the Jos Plateau of Nigeria (17 events), the North Mossi Plateau of Burkina Faso (10 events), and the Mandingue Plateau of Mali (24 events). While the elevation changes associated with these features are only around $200-400 \mathrm{~m}$, smaller than other orographic features of northern Africa, it is enough and focus the low-level wind convergence and promote some uplift to more consistently result in heavier rainfall events in their proximity.

Most of the MCSs associated with the top 100 events originate between $10^{\circ} \mathrm{N}-20^{\circ} \mathrm{N}$ (94 events) with a wide spread in the distance between the genesis and the maximum rainfall location. 25 events form within $100 \mathrm{~km}$ of the location of the rainfall maximum, 44 form $100-1000 \mathrm{~km}$ away, and $31 \mathrm{form}$ more than $1000 \mathrm{~km}$ away. In contrast to the location of maximum rainfall, the generation of less than half of the 100 events is associated with elevated terrain (Fig. 1b). The most active storm genesis area extends eastward along the Niger/Nigeria border from $5^{\circ} \mathrm{E}$ to east of Lake Chad. A variety of factors could explain why genesis is frequent here. For one, the area is a depression that gradually increases in slope westward from Lake Chad that promotes low-level upslope flow that can be important for triggering convection. Longitudinally the region lies near $10^{\circ} \mathrm{E}$, which is where the influence of low-level summer inflow of moisture from the Gulf of Guinea becomes more influential due to the shape of the continent, so there is a healthy moisture supply here. Latitudinally, the area lies in close proximity of where the AEW southern storm track is typically positioned meaning there are frequent atmospheric disturbances that traverse the region. The area is also just downstream of Lake Chad, which could also be influential as a moisture source and/or generating low-level convergence boundaries to help trigger the development of convection. Future work beyond this study is needed to better understand the relative roles of these above-mentioned factors.

Size of the 24-h rainfall totals exceeding $100 \mathrm{~mm}$ for most of the top 100 events is localized with areal coverage around $4,000 \mathrm{~km}^{2}$ or less (Fig. 3). For the 12 events large in size $\left(>20,000 \mathrm{~km}^{2}\right)$, half fall in the top 10 in terms of maximum 24-h total rainfall (Table 1), indicating that the top 10 events are more likely to be more impactful in terms of flooding potential at larger spatial scales. This is confirmed by cross- 
referencing with available FEWSNET reports, CRED EM-DAT disaster reports, OCHA Reliefweb, DREF bulletin reports, and any available extreme rainfall studies, as 9 of the top 10 events are associated with impactful flooding events (Table 2).

Composites formed from the top 100 events are used to better understand the atmospheric environmental conditions associated with these extreme cases. They are associated with a significant and widespread increase in precipitable water over the entire Sahel prior to the event (Fig. $4 \mathrm{~b}$ ). There is no evidence of a consistent or large change in the 600-925 hPa vertical wind shear (Fig. 4d) in association with this region's extreme rainfall events. This is consistent with Olaniyan et al. (2021), who also finds that vertical wind shear has a much weaker impact on higher precipitation totals than moisture availability for extreme rainfall events over Nigeria. In contrast, Taylor et al. (2017) and Klein et al. (2021) find that stronger wind shear is associated with more intense MCSs over West Africa. However, this difference can be understood when considering the methodology differences between the studies. In our study, we use 24-h total accumulated IMERG rainfall estimates to identify the top 100 extreme rainfall events selected for analysis. However, Taylor et al. (2017) and Klein et al. (2021) use Meteosat satellite cloud top temperature data to quantify the development of the MCS, as cloud-top temperatures are commonly used to estimate updraft velocities/convective intensity of the system (Cecil et al. 2005; Zipser et al. 2006). While this method identifies extreme weather systems with strong convective updrafts that extend to high altitudes, it does not necessarily translate into extreme rainfall rates at the surface, as the heaviest rainfall events are mostly found to be associated with less intense convection (Hamada et al. 2015).

The top 10 events are individually examined to evaluate storm development for the most extreme events. The events are organized into two categories. One is events with shorter duration $(<10.5 \mathrm{~h})$ and higher peak intensity rainfall $(>67 \mathrm{~mm})$, and the other is events with longer duration $(>15 \mathrm{~h}$ ) and weaker peak rainfall $(<57 \mathrm{~mm})$. The shorter duration/higher peak rainfall cases have peak rainfall occurring in the late afternoon/early evening prior to $00 \mathrm{Z}$, while the longer duration/weaker peak rainfall cases primarily peak between $00 Z$ - $03 Z$ (Fig. 5). The latter result is consistent with the full sample of 100 events (Fig. $6 c$ ), but the former is not because peak rainfall intensities can occur any time over the diurnal cycle (Fig. $6 a)$.

The location of maximum 24-h rainfall amount for the top 10 events is associated with a change in storm motion (Figs. 8). This can include a change in direction and/or speed, suggesting that convective reorganization occurs in response to environmental conditions. The size of the storm rain shield and intense convective core vary throughout the development process, with the convective core growing around the time of peak rainfall intensity (Fig. 9). In most instances this growth in the convective core size occurs while the MCS temporarily contracts. This generally persists for a couple of hours or less, then reverses as the MCS grows and the convective core contracts. The frequency of this oscillation varies from event to event.

The top 10 events are found to be associated with one of the following three atmospheric conditions: 
- \#1: Moisture preconditioning of the atmosphere: (CASE01, CASE03, CASE06): For CASE03 the enhanced moisture is associated with the passage of a preceding disturbance a day earlier that increases the atmospheric moisture west of $8^{\circ} \mathrm{E}$ starting on 24 August 2007 (Fig. 13d). For CASE01 (Fig. 11b) and CASE06 (Fig. 13f) conditions are anomalously wet across the entire Sahel for the entire 10-day analysis window. For these two cases the MJO may be influential. Inspection of the Daily Multivariate MJO Index provided by the Australian Government Bureau of Meteorology (Australian Bureau of Meteorology 2021) indicates that these two events are associated with a relatively strong MJO wet phase over tropical northern Africa. Past studies have indicated that boreal summer convective activity over West Africa and the Sahel increases during these phases as the associated circulation patterns enhance moisture loading over the West Africa Sahel and destabilize the environment (Matthews 2004; Janicot et al. 2009; Alaka Jr and Maloney 2012, 2014; Schlueter et al. 2019a,b).

\#2: Interaction of the storm in the wake of a region of anticyclonic flow and the Sahel/tropical Africa moisture northward into a developing system, while anticyclonic northerly/northwesterly flow ahead of the system displaces the Sahel/tropical Africa dryline boundary equatorward and enhances the southward infiltration of drier Sahelian air into the region. This circulation pattern results in an area of enhanced low-level convergence and an unstable environment ahead of the approaching disturbance in the area where the heavy rainfall is observed to occur. Past studies (Vizy and Cook 2018, 2019a) have shown that the Sahel/tropical Africa dryline can be a key environmental factor for the development of strong convection over the Sahel.

- \#3: Interaction of the storm in the wake of a region of anticyclonic flow (CASE02, CASE07, CASE10): This scenario is a variant of pattern \#2 that does not involve interactions with the dryline. The westward moving disturbance draws moisture into the system from the south and west even as the system moves into an anomalously dry large-scale environment dominated by anticyclonic flow. In two cases (CASE02 and CASE10; Figs. 13a and 11g), the systems slow as they approach anticyclonic ridging along the coast. This slow-down is consistent with a deceleration and/or temporary stalling of the wave disturbances observed over West Africa (Cornforth et al. 2017; Engel et al. 2017). The relatively close proximity of the coast also could be a factor (Reed et al. 1977; Thorncroft and Hodges 2001; Berry and Thorncroft 2005; Berry et al. 2007; Hamilton et al. 2017). Here, coastal ridging remains persistent and slow to break down (Figs. 11g and 13a) contributing to the deceleration of the disturbance as it approaches from the east. More work is needed to better understand the extent to which ridging varies and how this impacts the propagation of approaching disturbance.

This study identifies anomalously high atmospheric moisture content as an important environmental condition for the development of extreme rainfall events over the West African Sahel. Unlike some previous studies we do not find that large-scale vertical wind shear, for example, in association with the African easterly jet, plays an essential role. Of the top 100 events analyzed, only a little over half form in a strong vertical wind shear environment. While 8 of the top 10 events are associated with anomalously 
high vertical wind shear, the shear is localized and cause-and-effect is not discernible (Figs. 10, 12, and 14). A composite of the top 10024 -hr rain-producing events population does not show an association with vertical shear prior to the event (Fig. 4), so vertical wind shear is not a good predictor of an extreme rainfall event over the West African Sahel.

On climate change (decadal) time scales, these results suggest that increases in atmospheric moisture associated with surface warming, e.g., through the Clausius-Clapeyron relation, provide a mechanism for storm intensification. The large-scale vertical shear environment over the Sahel is observed to be changing - the mid-tropospheric African easterly jet is intensifying as large-scale meridional temperature gradients increase in association with amplified warming over the Sahara (Cook and Vizy 2015; Vizy and Cook 2017). The current results indicate that this intensification in the jet will not serve as a mechanism for storm intensification. However, additional research is needed to confirm this result and understand how localized shear impacts storm development.

\section{Declarations}

Funding: This work was funded by NSF Award \#1929074

Conflict of interest: Not applicable

Availability of data: All datasets analyzed in this study are freely available from their original sources.

Code availability: Not applicable

Acknowledgements: This work was funded by NSF Award \#1929074. The authors acknowledge the Texas Advanced Computing Center (TACC) at The University of Texas at Austin for providing HPC and database resources that have contributed these research results URL: http://www.tacc.utexas.edu. The Grid Analysis and Display System software (GrADS) developed at COLA/IGES was used for generating the figures.

\section{References}

1. Alaka GJ Jr, Maloney ED (2012) The influence of the MJO on upstream precursors to African easterly waves. J Clim 25:3219-3236. https://doi.org/10.1175/JCLI-D-11-00232.1

2. Alaka GJ Jr, Maloney ED (2014) The intraseasonal variability of African easterly wave energetics. J Clim 27:6559-6580. https://doi.org/10.1175/JCLI-D-14-00146.1

3. American Meteorological Society (2021) Intertropical front. Glossary of Meteorology. https://glossary.ametsoc.org/wiki/Intertropical_front

4. Anash SO, Ahiatahu MA, Yorke CK, Out-Larbi F, Yahaya B, Lamptey PNL, Tanu M (2020) Meteorological analysis of floods in Ghana. Advances in Meteorol 4230627:1-14. https://doi.org/10.1155/2020/4230627 
5. Australian Bureau of Meteorology (2021) Madden-Julian Oscillation.

http://www.bom.gov.au/climate/mjo/. Accessed 25 Feb 2021

6. Barnes GM, Sieckman K (1984) The environment of fast- and slow-moving tropical mesoscale convective cloud lines. Mon Wea Rev 112: 1782-1794. https://doi.org/10.1175/15200493(1984)112,1782:TEOFAS.2.0.C0;2

7. Berry G, Thorncroft C (2005) Case study of an intense African easterly wave. Mon Wea Rev 133:752766. https://doi.org/10.1175/MWR2884.1

8. Berry G, Thorncroft C, Hewson T (2007) African easterly waves during 2004 - Analysis using objective techniques. Mon Wea Rev 135:1251-1267. https://doi.org/10.1175/MWR3343.1

9. Burpee RW (1972) The origin and structure of easterly waves in the lower troposphere of North Africa. J Atmos Sci 29: 77-90. https://doi.org/10.1175/15200469(1972)029<0077:TOASOE>2.0.C0;2

10. Carlson TN (1969a) Synoptic histories of three African disturbances that developed into Atlantic hurricanes. Mon Wea Rev 97: 256-276. https://doi.org/10.1175/15200493(1969)097,0256:SHOTAD.2.3.C0;2

11. Carlson TN (1969b) Some remarks on African disturbances and their progress over the tropical Atlantic. Mon Wea Rev 97: 716-726. https://doi.org/10.1175/15200493(1969)097<0716:SROADA>2.3.C0;2

12. Carlson TN, Benjamin SG, Forbes GS (1983) Elevated mixed layers in the regional severe storm environment: conceptual model and case studies. Mon Weather Rev 111:1453-1473. https://doi.org/10.1175/1520-0493(1983)111<1453:EMLITR>2.0.C0;2

13. Cecil DJ, Goodman SJ, Boccippio DJ, Zipser EJ, Nesbitt SW (2005) Three years of TRMM precipitation features. Part I: Radar, radiometric, and lightning characteristics. Mon Wea Rev 133:543-566. https://doi.org/10.1175/MWR-2876.1

14. Cook KH (1997) Large-scale atmospheric dynamics and Sahelian precipitation. J Climate 10: 11371152. https://doi.org/10.1175/1520-0442(1997)010<1137:LSADAS>2.0.C0;2

15. Cook KH (2015) Role of intertial instability in the West African monsoon jump. J Geophys Res Atmos 120:3085-3102. https://doi.org/10.1002/2014JD022579

16. Cook KH, Vizy EK (2015) Detection and analysis of an amplified warming of the Sahara Desert. J Clim 28:6560-6580. https://doi.org/10.1175/JCLI-D-14-00230.1

17. Copernicus Climate Change Service (C3S) (2020) ERA5: Fifth generation of ECMWF atmospheric reanalyses of the global climate. Copernicus Climate change Service Climate Data Store (CDS), Accessed 1 June 2020. https://cds.climate.copernicus.edu/cdsapp\#!/home

18. Cornforth RJ, Mumba Z, Parker DJ et al (2017) Synoptic systems. Meteorology of Tropical West Africa: The Forecasters' Handbook, Parker DJ, Diop-Kane M (eds), Wiley-Blackwell, pp 40-89, https://doi.org/10.1002/9781118391297.ch2

19. Danso DK, Anquetin S, Diedhiou A, Lavaysse C, Kobea A, Touré NE (2019) Spatio-temporal variability of cloud cover types in West Africa with satellite-based and reanalysis data. Q J Roy Meteorol Soc 
145:3715-3731. https://doi.org/10.1002/qj.3651

20. Desbois M., Kayiranga T, Gnamien B, Guessous S, Picon L (1988) Characterization of some elements of the Sahelian climate and their interannual variations for July 1983, 1984, and 1985 from the analysis of Meteosat ISCCP data. J Clim 9: 867-904. https://doi.org/10.1175/15200442(1988)001<0867:COSEOT>2.0.C0;2

21. Dezfuli AK, Ichoku CM, Huffman GJ, Mohr KI et al (2017) Validation of IMERG precipitation in Africa. J Hydrometeorol 18:2817-2825. https://doi.org/10.1175/JHM-D-17-0139.1

22. Di-Baldassarre G, Montanari A, Lins H, Koutsoyiannis D, Brandimarte L, Blöschl G (2010) Flood fatalities in Africa: From diagnosis to mitigation. Geophys Res Lett 37:1-5. https://doi.org/10.1029/2010GL045467

23. Diehiou A, Janicot S, Viltard A, de Felice P, Laurent H (1999) Easterly wave regimes and associated convection over West Africa and tropical Atlantic: Results from the NCEP/NCAR and ECMWF reanalyses. Clim Dyn 15:795-822. https://doi.org/10.1007/s003820050316

24. Dione C, Lothon M, Badiane D, Campistron B, Couvreux F, Guichard F, Salle S (2014) Phenomenology of Sahelian convection observed in Niamey during the early monsoon. Q J R Meteorol Soc 140:500516. https://doi.org/10.1002/qj.2149

25. Doswell CA III, Brooks HE, Maddox RA (1996) Flash flood forecasting: An ingredients-based methodology. Wea Forecasting 11: 560-581. https://doi.org/10.1175/15200434(1996)011<0560:FFFAIB>2.0.CO;2

26. Douglas I, Alam K, Maghenda M, McDonnell Y, McLean L, Campbell J (2008) Unjust waters: Climate change, flooding and the poor in Africa. Environ Urban 20:187-205. https://doi.org/10.1177/0956247808089156

27. Duvel J-P (1989) Convection over tropical Africa and the Atlantic Ocean during northern summer. Part I: Interannual and diurnal variations. Mon Wea Rev 117: 2782-2799.

https://doi.org/10.1175/1520-0493(1989)117<2782:COTAAT>2.0.C0;2

28. Eldridge RH (1957) A synoptic study of West African disturbance lines. Q J Roy Meteorol Soc 83:303-314. https://doi.org/10.1002/qj.49708335704

29. EM-DAT (2020) EM-DAT: The OFDA/CRED International Disaster Database, https://www.emdat.be/, accessed 1 June 2020

30. Engel T, Fink AH, Knippertz P, Pante G (2017) Extreme precipitation in the West African cities of Dakar and Ouagadougou: Atmospheric dynamics and implications for flood risk assessments. J Hydrometeorol 18:2937-2957. https://doi.org/10.1175/JHM-D-16-0218.1

31. FEWS NET (2020) The Famine Early Warning System Network, USAID, https://fews.net/, accessed 15 May 2020

32. Fink AH, Reiner A (2003) Spatiotemporal variability of the relation between African easterly waves and West African squall lines in 1998 and 1999. J Geophys Res 108:4332. https://doi.org/10.1029/2002JD002816 
33. Fitzpatrick RGJ, Parker DJ, Marsham JH, Rowell DP, Guichard FM, Taylor CM, Cook KH, Vizy EK, Jackson LS, Finney D, Crook J, Stratton R, Tucker S (2020) What drives the intensification of mesoscale convective systems over the West African Sahel under climate change? J Climate 33:3151-3172. https://doi.org/10.1175/JCLI-D-19-0380.1

34. Galvin JFP (2010) Two easterly waves in West Africa in summer of 2009. Weather 65:219-227. https://doi.org/10.1002/wea.605

35. Gaona MFR, Overeem A, Leijnse H, Uijlenhoet R (2016) First-year evaluation of GPM rainfall over The Netherlands: IMERG day 1 final run (V03D). J Hydrometeor 17:2799-2814. https://doi.org/10.1175/JHM-D-16-0087.1

36. Giorgi F, Im E-S, Coppola E, Diffenbaugh NS, Gao XJ, Mariotti L, Shi Y (2011) Higher hydroclimatic intensity with global warming. J Clim 24:5309-5324. https://doi.org/10.1175/2011JCLI3979.1

37. Hagos S, Zhang C Diabatic heating, divergent circulation and moisture transport in the African monsoon system. Quart J Roy Meteorol Soc 136: 411-425. https://doi.org/10.1002/qj.538

38. Hamada A, Takayabu YN, Liu C, Zipser EJ (2015) Weak linkage between the heaviest rainfall and tallest storms. Nat Commun 6:6213. https://doi.org/10.1038/NCOMMS7213

39. Hamilton HL, Young GS, Evans JL, Fuentes JD, Núñez Ocasio KM (2017) The relationship between the Guinea Highlands and the West African offshore rainfall maximum. Geophys Res Lett 44:11581166. https://doi.org/10.1002/2016GL071170

40. Hamilton RA, Archbold (1945) Meteorology of Nigeria and adjacent territory. Quart J Roy Meteorol Soc 71:231-264. https://doi.org/10.1002/qj.49707130905

41. Han F, Cook KH, Vizy EK (2019) Changes in intense rainfall events and drought across Africa in the 21st century. Clim Dyn 53:2757-2777. https://doi.org/10.1007/s00382-019-04653-z

42. Hastenrath S, Lamb P (1977) Some aspects of circulation and climate over the eastern equatorial Atlantic. Mon Wea Rev 105: 1019-1023. https://doi.org/10.1175/1520-

0493(1977)105<1019:SAOCAC>2.0.CO;2

43. Hodges KI, Thorncroft CD (1997) Distribution and statistics of African mesoscale convective weather systems based on ISCCP METEOSAT imagery. Mon Wea Rev 125: 2821-2837. https://doi.org/10.1175/1520-0493(1997)125<2821:DASOAM>2.0.CO;2

44. Hou AY et al (2014) The Global Precipitation Measurement mission. Bull Amer Meteor Soc 95:701722. https://doi.org/10.1175/BAMS-D-13-00164.1

45. Hsieh J-S, Cook KH (2005) Generation of African easterly wave disturbances: Relationship to the African easterly jet. Mon Wea Rev 133:1311-1327. https://doi.org/10.1175/MWR2916.1

46. Hsieh J-S, Cook KH (2008) On the instability of the African easterly jet and the generation of African waves: Reversals of the potential vorticity gradient. J Atmos Sci 65:2130-2151. https://doi.org/10.1175/2007JAS2552.1

47. Huffman GJ, Bolvin DT, Braithwaite D, Hsu K, Joyce R, Kidd C, Nelkin EJ, Sorooshian S, Tran J, Xie P (2020) NASA Global Precipitation Measurement (GPM) Integrated Multi-satellitE Retrievals for GPM 
(IMERG). Algorithm Theoretical Basis Doc., version 6.3, 30 pp., https://gpm.nasa.gov/sites/default/files/2020-05/IMERG_ATBD_V06.3.pdf

48. Janicot S, Mounier F, Hall NMJ, Leroux S, Sultan B, Kiladis GN (2009) The West African Monsoon dynamics. Part IV: Analysis of the 25-90 day variability of convection and the role of the Indian Monsoon. J Clim 22:1541-1565

49. Janicot S, and Coauthors (2011) Intraseasonal variability of the West African monsoon. Atmos Sci Lett 12:58-66. https://doi.org/10.1002/asl.280

50. Kendon EJ, Stratton RA, Tucker S, Marsham JH, Berthou S, Rowell DP, Senior CA (2019) Enhanced future changes in wet and dry extremes over Africa and convection-permitting scale. Nat Commun 10:1794. https://doi.org/10.1038/s41467-019-09776-9

51. Kidd C, Levizzani V (2011) Status of satellite precipitation retrievals. Hydrol Earth Syst Sci 15:11091116. https://doi.org/10.5194/hess-15-1109-2011

52. Klein C, Nkrumah F, Taylor CM, Adefisan EA (2021) Seasonality and trends of drivers of mesoscale convective systems in southern West Africa. J Climate 34:71-87. https://doi.org/10.1175/JCLI-D-200194.1

53. Knippertz P, Martin JE (2005) Tropical plumes and extreme precipitation in subtropical and tropical West Africa. Q J R Meteorol Soc 131:2337-2365. https://doi.org/10.1256/qj.04.148

54. Kundzewicz ZW, Kanae S, Seneviratne SI, Handmer J et al (2014) Flood risk and climate change: Global and regional perspectives. Hydrol Sci J 59:1-28. https://doi.org/10.1080/02626667.2013.857411

55. Laing AG, Fritsch JM (1993) Mesoscale convective complexes in Africa. Mon Wea Rev 121: 22542263. https://doi.org/10.1175/1520-0493(1993)121<2254:MCCIA>2.0.CO;2

56. Laing AG, Fritsch JM, Negri AJ (1999) Contribution of mesoscale convective complexes to rainfall in Sahelian Africa: Estimates from geostationary infrared and passive microwave data. J Appl Meteorol 38: 957-964. https://doi.org/10.1175/1520-0450(1999)038<0957:COMCCT>2.0.CO;2

57. Laing AG, Carbone R, Levizzani V, Tuttle J (2008) The propagation and diurnal cycles of deep convection in northern tropical Africa. Quart J Roy Meteorol Soc 134:93-109. https://doi.org/10.1002/qj.194

58. Laurent H, D'Amato N, Lebel T (1998) How important is the contribution of the mesoscale convective complexes to the Sahelian rainfall? Phys Chem Earth 23:629-633. https://doi.org/10.1016/S00791946(98)00099-8

59. Lélé MI, Lamb PJ (2010) Variability of the Intertropical front (ITF) and rainfall over the West African Sudan-Sahel zone. J Climate 23:3984-4004. https://doi.org/10.1175/2010JCLI3277.1

60. Leroux S, Hall NMJ (2009) On the relationship between African easterly waves and the African easterly jet. J Atmos Sci 66:2303-2316. https://doi.org/10.1175/2009JAS2988.1

61. Li F, Chavas DR, Reed KA, Dawson IIDT (2020) Climatology of severe local storm environments and synoptic-scale features over North America in ERA5 reanalysis and CAM6 simulation. J Climate. https://doi.org/10.1175/JCLI-D-19-0986.1 
62. Liu W, Cook KH, Vizy EK (2019) The role of mesoscale convective systems in the diurnal cycle of rainfall and its seasonality over sub-Saharan Northern Africa. Clim Dyn 52:729-745. https://doi.org/10.1007/s00382-018-4162-y

63. Magami IM, Yahaya S, Mohammed K (2014) Causes and consequences of flooding in Nigeria: A review. Biological Environmental Sci J for the Tropics 11:154-162

64. Maranan M, Fink AH, Knippertz P, Amekudzi LK, Atiah WA, Stengel M (2020) A process-based validation of GPM IMERG and its sources using a mesoscale rain gauge network in the West African forest zone. J Hydrometeorol 21:729-749. https://doi.org/10.1175/JHM-D-19-0257.1

65. Marsham JH, Dixon N, Garcia-Carreras L, Lister G, Parker DJ, Knippertz P, Birch C (2013) The role of moist convection in the West African monsoon system-insights from continental-scale convectionpermitting simulations. Geophys Res Lett 40:1843-1849. https://doi.org/10.1002/grl.50347

66. Mathon V, Laurent $\mathrm{H}$, Lebel T (2002) Mesoscale convective system rainfall in the Sahel. J Appl Meteorol 41: 1081-1092. https://doi.org/10.1175/1520-0450(2002)041<1081:MCSRIT>2.0.C0;2

67. Matthews AJ (2004) Intraseasonal variability over tropical Africa during northern summer. J Climate 17: 2427-2440. https://doi.org/10.1175/1520-0442(2004)017<2427:IVOTAD>2.0.C0;2

68. Mekonnen A, Thorncroft CD, Aiyyer A (2006) Analysis of convection and its association with African easterly waves. J Climate 19:5405-5421. https://doi.org/10.1175/JCLI3920.1

69. Mohr KI (2004) Interannual, monthly, and regional variability in the wet season diurnal cycle of precipitation in sub-Saharan Africa. J Climate 17: 2441-2453. https://doi.org/10.1175/15200442(2004)017<2441:IMARVI>2.0.C0;2

70. Mohr KI, Thorncroft CD (2006) Intense convective systems in West Africa and their relationship to the African easterly jet. Q J Roy Meteorol Soc 132:163-176. https://doi.org/10.1256/qj.05.55

71. Nair S, Srinivasan G, Nemani R (2009) Evaluation of multi-satellite TRMM derived rainfall estimates over a western state of India. J Meteor Soc Japan 87:927-939.

https://doi.org/10.2151/JMSJ.87.927

72. Nicholson SE et al (2003) Validation of TRMM and other rainfall estimates with a high-density gauge dataset for West Africa. Part II: Validation of TRMM rainfall products. J Appl Meteor 42: 1355-1368. https://doi.org/10.1175/1520-0450(2003)042,1355:VOTAOR.2.0.CO;2

73. Panthou G, Vischel T, Lebel T (2014) Short Communication: Recent trends in the regime of extreme rainfall in the Central Sahel. Int J Climatol 34:3998-4006. https://doi.org/10.1002/joc.3984

74. Parker DJ, Burton RR, Diongue-Niang A, Ellis RJ, Felton M, Taylor CM, Thorncroft CD, Bessemoulin P, Tompkins AM (2005) The diurnal cycle of the West African monsoon circulation. Quart J Roy Meteorol Soc 131:2839-2860. https://doi.org/10.1256/qj.04.52

75. Peters M. Tetzlaff G (1988) The structure of West African squall lines and their environmental moisture budget. Meteorol Atmos Phys 39:74-84. https://doi.org/doi:10.1007/BF01041933

76. Pfeifroth U, Mueller R, Ahrens B (2013) Evaluation of satellite-based and reanalysis precipitation data in the tropical Pacific. J Appl Meteor Climatol 52:634-644. https://doi.org/10.1175/JAMC-D-12049.1 
77. Pfeifroth U, Trentmann J, Fink AH, Ahrens B (2016) Evaluating satellite-based diurnal cycles of precipitation in the African tropics. J Applied Meteorol Climatol 55:23-38. https://doi.org/10.1175/JAMC-D-15-0065.1

78. Provod M, Marsham JH, Parker DJ, Birch CE (2016) A characterization of cold pools in the West African Sahel. Mon Weather Rev 144:1924-1934. https://doi.org/10.1175/MWR-D-15-0023.1

79. Redelsperger JL, Lafore JP (1988) A three-dimensional simulation of a tropical squall-line: convective organization and thermodynamic vertical transport. J Atmos Sci 45:1334-1356. https://doi.org/10.1175/1520-0469(1988)045<1334:ATDSOA>2.0.CO;2

80. Reed RJ, Norquist DC, Recker EE (1977) The structure and properties of African wave disturbances as observed during Phase III of GATE. Mon Wea Rev 105: 317-333. https://doi.org/10.1175/15200493(1977)105<0317:TSAPOA>2.0.C0;2

81. Roca R, Chambon P, Jobard I, Kirstetter P-E, Gosset M, Bergès JC (2010) Comparing satellite and surface rainfall products over West Africa at meteorologically relevant scales during the AMMA campaign using error estimates. J Appl Meteor Climatol 49:715-731. https://doi.org/10.1175/2009JAMC2318.1

82. Rotunno R, Klemp JB, Weisman ML (1988) A theory for strong, long-lived squall lines. J Atmos Sci 45:463-485. https://doi.org/10.1175/1520-0469(1988)045<0463:ATFSLL>2.0.C0;2

83. Rowell DP, Milford JR (1993) On the generation of African squall lines. J Clim 6: 1181-1193. https://doi.org/10.1175/1520-0442(1993)006<1181:OTGOAS>2.0.CO;2

84. Samimi C, Fink AH, Paeth H (2012) The 2007 flood in the Sahel: Causes, characteristics and its presentation in the media and FEWS NET. Nat Hazards Earth Syst Sci 12:313-325. https://doi.org/10.5194/nhess-12-313-2012

85. Schlueter A, Fink AH, Knippertz P, Vogel P (2019a) A systematic comparison of tropical waves over Northern Africa. Part I: Influence on rainfall. J Clim 32:1501-1523. https://doi.org/10.1175/JCLI-D18-0173.1

86. Schlueter A, Fink AH, Knippertz P (2019b) A systematic comparison of tropical waves over Northern Africa. Part Il: Dynamics and thermodynamics. J Clim 32:2605-2625. https://doi.org/10.1175/JCLID-18-0651.1

87. Tapiador FJ, Navarro A et al (2020) The contribution of rain gauges in the calibration of IMERG product: Results from the first validation over Spain. J Hydrometeorol 21:161-182. https://doi.org/10.1175/JHM-D-19-0116.1

88. Tarhule A (2005) Damaging rainfall and flooding: The other Sahel hazards. Clim Change 72:355377. https://doi.org/10.1007/s10584-005-6792-4

89. Taylor CM, Belušić D, Guichard F, Parker DJ, Vischel T, Brock O, Harris PP, Janicot S, Klien C, Panthou G (2017) Frequency of extreme Sahelian storms tripled since 1982 in satellite observations. Nature 544:475-478. https://doi.org/10.1038/nature22069

90. Tetzlaff G, Peters M (1988) A composite study of early summer squall lines and their environment over West Africa. Meteorol Atmos Phys 38:153-163. https://doi.org/10.1007/BF01029779 
91. Thorncroft C, Hodges K (2001) African easterly wave variability and its relationship to Atlantic tropical cyclone activity. J Climate 14: 1166-1179. https://doi.org/10.1175/15200442(2001)014<1166:AEWVAl>2.0.C0;2

92. Thorncroft CD, Ngyyen H, Zhang C, Peyrillé P (2011) Annual cycle of the West African monsoon: Regional circulations and associated water vapour transport. Quart J Roy Meteorol Soc 137:129147. https://doi.org/10.1002/qj.728

93. Tramblay Y, Villarini G, Zhang W (2020) Observed changes in flood hazard in Africa. Environ Res Lett 15:1040b5. https://doi.org/10.1088/1748-9326/abb90b

94. Trier SB, Chen F, Manning KW (2004) A study of convective initiation in a mesoscale model using high-resolution land surface initial conditions. Mon Wea Rev 132:2954-2976. https://doi.org/10.1175/MWR2839.1

95. Trier SB, Romine GS, Ahuevych DA (2015) Mesoscale thermodynamic influences on convection initiation near a surface dryline in a convection-permitting ensemble. Mon Wea Rev 143:3726-3753. https://doi.org/10.1175/MWR-D-15-0133.1

96. Tschakert P, Sagoe R, Ofori-Darko G, Codjoe SN (2010) Floods in the Sahel: An analysis of anomalies, memory, and anticipatory learning. Clim Change 103:471-502. https://doi.org/10.1007/s10584-0099776-y

97. Vizy EK, Cook KH (2017) Seasonality of the observed amplified Sahara warming trend and implications for Sahel rainfall. J Clim 30:3073-3094. https://doi.org/10.1175/JCLI-D-16-0687.1

98. Vizy EK, Cook KH (2018) Mesoscale convective systems and nocturnal rainfall over the West African Sahel: Role of the Inter-tropical front. Clim Dyn 50:587-614. https://doi.org/10.1007/s00382-0173628-7

99. Vizy EK, Cook KH (2019a) Understanding the summertime diurnal cycle of precipitation over subSaharan West Africa: Regions with daytime rainfall peaks in the absence of significant topographic features. Clim Dyn 52:2903-2922. https://doi.org/10.1007/s00382-018-4315-z

100. Vizy EK, Cook KH (2019b) Observed relationship between the Turkana low-level jet and boreal summer convection. Clim Dyn 53:4037-4058. https://doi.org/10.1007/s00382-019-04769-2

101. Vondou DA (2012) Spatio-temporal variability of Western Central African convection from infrared observations. Atmosphere 3:377-399. https://doi.org/10.3390/atmos3030377

102. Watters D, Battaglia A, Mroz K, Tridon F (2018) Validation of the GPM Version-5 surface rainfall products over Great Britain and Ireland. J Hydrometeorol 19:1617-1636. https://doi.org/10.1175/JHM-D-18-0051.1

103. Weisman ML, Rotunno R (2004) "A theory for strong long lived squall lines" revisited. J Atmos Sci 61: 361-382. https://doi.org/10.1175/1520-0469(2004)061,0361:ATFSLS.2.0.C0;2

104. Zahiri E-P, Bamba I, Famien AM, Koffi AK, Ochou AD (2016) Mesoscale extreme rainfall events in West Africa: The cases of Niamey (Niger) and the Upper Ouémé Valley (Benin). Wea Clim Extremes 13:15-34. https://doi.org/10.1016/j.wace.2016.05.001 
105. Zhang G, Cook KH, Vizy EK (2016a) The diurnal cycle of warm season rainfall over West Africa. Part I: Observational analysis. J Clim 29:8423-8437. https://doi.org/10.1175/JCLI-d-15-0874.1

106. Zhang G, Cook KH, Vizy EK (2016b) The diurnal cycle of warm season rainfall over West Africa. Part II: Convection-permitting simulations. J Clim 29:8439-8454. https://doi.org/10.1175/JCLI-d-150875.1

107. Zhao S, Cook KH, Vizy EK (2021) How shrinkage of Lake Chad affects the local climate. Submitted Clim Dyn

108. Zipser EJ (1977) Mesoscale and convective-scale downdrafts as distinct components of squall-line structure. Mon Wea Rev 105: 1568-1589. https://doi.org/10.1175/1520-

0493(1977)105<1568:MACDAD>2.0.C0;2

109. Zipser EJ, Cecil DJ, Liu C, Nesbitt SW, Yorty DP (2006) Where are the most intense thunderstorms on Earth? Bull Amer Meteor Soc 87:1057-1071. https://doi.org/10.1175/BAMS-87-8-1057

\section{Tables}

Table 1. Listing of the top 100 rainfall events identified for the Sahel analysis region. 


\begin{tabular}{|c|c|c|c|c|c|c|c|}
\hline $\begin{array}{l}\text { CASE } \\
\text { ID }\end{array}$ & Date & $\begin{array}{l}\text { Lon. } \\
\left({ }^{\circ} \mathrm{E}\right)\end{array}$ & $\begin{array}{l}\text { Lat. } \\
\left({ }^{\circ} \mathrm{N}\right)\end{array}$ & $\begin{array}{l}\text { rainfall } \\
(\mathrm{mm})\end{array}$ & $\begin{array}{l}\text { Intensity } \\
(\mathrm{mm} / \mathrm{h})\end{array}$ & $\begin{array}{l}\text { Duration } \\
\text { (h) }\end{array}$ & $\begin{array}{l}\text { Shear } \\
\text { Strength }\end{array}$ \\
\hline 1 & 20-21 AUG 2019 & 9.85 & 16.15 & 291.2 & 77.40 & 8.0 & stronger \\
\hline 2 & 07-08 AUG 2012 & -6.35 & 12.55 & 280.8 & 52.67 & 19.5 & stronger \\
\hline 3 & 26-27 AUG 2007 & -2.25 & 12.15 & 262.8 & 33.82 & 16.5 & weaker \\
\hline 4 & 06-07 AUG 2001 & 8.35 & 12.25 & 254.3 & 70.28 & 10.5 & stronger \\
\hline 5 & 04-05 AUG 2007 & -2.55 & 13.55 & 242.7 & 57.99 & 11.0 & stronger \\
\hline 6 & 23-24 AUG 2019 & -6.75 & 13.65 & 225.1 & 30.42 & 15.5 & stronger \\
\hline 7 & 01-02 SEP 2009 & -7.85 & 13.15 & 225.0 & 91.77 & 12.0 & stronger \\
\hline 8 & 19-20 JUL 2001 & 9.05 & 12.45 & 207.8 & 80.97 & 9.5 & stronger \\
\hline 9 & 14-15 JUL 2007 & -5.65 & 13.25 & 203.1 & 47.48 & 15.5 & weaker \\
\hline 10 & 19-20 JUL 2004 & -7.75 & 12.55 & 197.7 & 67.61 & 8.5 & stronger \\
\hline 11 & 03-04 SEP 2010 & -7.95 & 13.65 & 197.2 & 57.45 & 9.5 & weaker \\
\hline 12 & 12-13 AUG 2005 & 11.35 & 12.65 & 192.7 & 69.01 & 7.0 & weaker \\
\hline 13 & 28-29 AUG 2007 & 8.85 & 15.15 & 191.0 & 76.70 & 7.5 & weaker \\
\hline 14 & 26-27 AUG 2005 & -7.25 & 13.55 & 188.2 & 77.43 & 13.0 & stronger \\
\hline 15 & 22-23 AUG 2006 & -4.15 & 13.45 & 188.1 & 55.57 & 16.5 & weaker \\
\hline 16 & 12-13 JUL 2003 & -7.55 & 13.25 & 187.9 & 66.66 & 6.5 & stronger \\
\hline 17 & 05-06 AUG 2005 & 11.35 & 13.65 & 187.0 & 60.31 & 7.5 & weaker \\
\hline 18 & 10-11 AUG 2006 & 6.25 & 12.65 & 185.4 & 70.99 & 11.0 & stronger \\
\hline 19 & 14-15 AUG 2008 & 9.55 & 12.05 & 184.9 & 71.22 & 8.5 & stronger \\
\hline 20 & 06-07 AUG 2004 & -3.15 & 15.65 & 182.6 & 53.88 & 10.5 & stronger \\
\hline 21 & 03-04 AUG 2006 & -0.15 & 13.75 & 182.0 & 68.96 & 11.0 & stronger \\
\hline 22 & 05-06 ОСТ 2002 & -6.85 & 13.25 & 180.4 & 71.61 & 13.0 & stronger \\
\hline 23 & 24-25 JUL 2003 & -7.95 & 12.75 & 178.5 & 59.38 & 9.5 & weaker \\
\hline 24 & 08-09 AUG 2001 & 5.85 & 16.95 & 177.2 & 58.83 & 4.5 & weaker \\
\hline 25 & 27-28 JUL 2000 & 8.45 & 12.85 & 175.8 & 51.55 & 9.0 & stronger \\
\hline 26 & 12-13 AUG 2001 & 7.65 & 12.35 & 173.9 & 68.26 & 8.5 & stronger \\
\hline
\end{tabular}




\begin{tabular}{|c|c|c|c|c|c|c|c|}
\hline 27 & 20-21 AUG 2013 & 3.15 & 13.35 & 173.6 & 69.95 & 9.5 & stronger \\
\hline 28 & 06-07 AUG 2003 & -5.15 & 15.15 & 172.3 & 46.79 & 12.5 & stronger \\
\hline 29 & 13-14 JUL 2006 & -7.05 & 13.15 & 172.2 & 39.76 & 8.5 & weaker \\
\hline 30 & 02-03 AUG 2005 & -7.75 & 12.05 & 169.8 & 60.76 & 7.5 & stronger \\
\hline 31 & $\begin{array}{l}31 \text { AUG - } 01 \text { SEP } \\
2009\end{array}$ & -1.45 & 12.65 & 169.2 & 59.88 & 9.5 & weaker \\
\hline 32 & 14-15 AUG 2003 & -7.35 & 12.55 & 167.8 & 70.64 & 12.0 & stronger \\
\hline 33 & 18-19 AUG 2011 & -6.55 & 14.05 & 167.5 & 37.13 & 8.5 & weaker \\
\hline 34 & 07-08 AUG 2004 & 7.65 & 12.35 & 166.8 & 52.20 & 10.0 & stronger \\
\hline 35 & 23-24 AUG 2003 & -7.55 & 12.25 & 165.3 & 50.86 & 13.5 & stronger \\
\hline 36 & 05-06 AUG 2019 & -7.35 & 14.25 & 165.2 & 51.78 & 12.0 & weaker \\
\hline 37 & 19-20 ОСТ 2008 & -7.65 & 12.45 & 164.7 & 57.18 & 7.5 & weaker \\
\hline 38 & 13-14 AUG 2012 & 9.65 & 12.05 & 163.8 & 59.15 & 9.5 & stronger \\
\hline 39 & 02-03 AUG 2001 & 9.95 & 12.05 & 163.6 & 54.51 & 9.5 & stronger \\
\hline 40 & 19-20 JUL 2000 & 6.75 & 12.25 & 162.9 & 50.37 & 11.0 & weaker \\
\hline 41 & 11-12 AUG 2001 & 9.45 & 12.15 & 162.5 & 50.32 & 6.5 & stronger \\
\hline 42 & 08-09 JUL 2001 & 8.45 & 12.55 & 162.1 & 60.75 & 6.0 & weaker \\
\hline 43 & 19-20 JUL 2010 & -7.55 & 12.95 & 162.0 & 40.89 & 13.5 & stronger \\
\hline 44 & 24-25 AUG 2005 & 11.65 & 12.35 & 162.0 & 50.20 & 10.0 & stronger \\
\hline 45 & 18-19 SEP 2010 & -8.05 & 12.85 & 161.7 & 55.73 & 14.0 & weaker \\
\hline 46 & 04-05 AUG 2011 & -7.85 & 14.45 & 161.5 & 60.51 & 8.0 & stronger \\
\hline 47 & 10-11 ОСТ 2008 & -7.85 & 12.15 & 161.3 & 74.00 & 5.0 & weaker \\
\hline 48 & $\begin{array}{l}31 \mathrm{JUL} \text { - } 01 \text { AUG } \\
2019\end{array}$ & -3.85 & 12.15 & 161.0 & 51.90 & 11.0 & weaker \\
\hline 49 & 16-17 JUL 2017 & 6.05 & 12.05 & 160.9 & 52.86 & 13.5 & weaker \\
\hline 50 & 24-25 AUG 2011 & -5.15 & 12.05 & 160.1 & 44.21 & 12.0 & stronger \\
\hline 51 & 19-20 AUG 2000 & 7.55 & 12.45 & 159.9 & 49.36 & 10.0 & stronger \\
\hline 52 & 22-23 AUG 2004 & -0.95 & 12.15 & 159.5 & 41.49 & 10.5 & weaker \\
\hline 53 & 22-23 AUG 2007 & 7.65 & 12.75 & 158.8 & 48.53 & 11.5 & weaker \\
\hline 54 & 14-15 AUG 2010 & -6.95 & 13.55 & 158.6 & 50.82 & 9.5 & stronger \\
\hline
\end{tabular}




\begin{tabular}{|c|c|c|c|c|c|c|c|}
\hline 55 & 18-19 JUN 2005 & 8.45 & 12.15 & 158.1 & 43.34 & 14.0 & weaker \\
\hline 56 & 15-16 AUG 2000 & 6.45 & 12.55 & 157.7 & 50.60 & 11.0 & stronger \\
\hline 57 & 07-08 SEP 2008 & -5.15 & 15.25 & 157.6 & 42.75 & 8.5 & stronger \\
\hline 58 & 16-17 SEP 2010 & -2.65 & 12.35 & 157.3 & 71.07 & 9.5 & weaker \\
\hline 59 & 25-26 AUG 2006 & -8.05 & 14.65 & 157.3 & 72.45 & 9.0 & weaker \\
\hline 60 & 20-21 JUL 2004 & -7.55 & 14.15 & 156.8 & 59.34 & 6.5 & weaker \\
\hline 61 & 30-31 JUL 2007 & 5.55 & 12.55 & 156.4 & 66.85 & 6.5 & weaker \\
\hline 62 & 17-18 AUG 2001 & 6.95 & 12.95 & 156.3 & 66.46 & 11.5 & stronger \\
\hline 63 & 23-24 AUG 2012 & -6.75 & 12.25 & 155.7 & 31.69 & 9.0 & stronger \\
\hline 64 & 18-19 JUL 2008 & 0.35 & 12.25 & 155.4 & 39.72 & 17.5 & stronger \\
\hline 65 & $\begin{array}{l}31 \mathrm{JUL}-01 \text { AUG } \\
2014\end{array}$ & 9.95 & 12.05 & 155.0 & 38.99 & 16.0 & stronger \\
\hline 66 & 23-24 JUL 2000 & 5.15 & 12.65 & 154.8 & 88.77 & 4.5 & weaker \\
\hline 67 & 04-05 AUG 2015 & -2.25 & 13.45 & 154.0 & 59.58 & 10.0 & weaker \\
\hline 68 & 02-03 AUG 2003 & 4.55 & 12.85 & 153.6 & 79.75 & 8.5 & weaker \\
\hline 69 & 12-13 AUG 2007 & 3.45 & 12.05 & 152.8 & 69.51 & 7.0 & stronger \\
\hline 70 & 24-25 AUG 2008 & 0.95 & 12.25 & 152.5 & 46.06 & 11.5 & weaker \\
\hline 71 & 26-27 AUG 2004 & -4.65 & 15.05 & 152.1 & 58.91 & 12.0 & weaker \\
\hline 72 & 17-18 AUG 2007 & 7.15 & 12.45 & 151.5 & 59.53 & 6.0 & weaker \\
\hline 73 & 25-26 JUL 2003 & 7.95 & 12.35 & 151.5 & 56.51 & 7.5 & weaker \\
\hline 74 & 20-21 AUG 2007 & -1.55 & 12.55 & 151.4 & 85.78 & 8.5 & stronger \\
\hline 75 & 27-28 SEP 2006 & -1.75 & 13.25 & 151.1 & 67.99 & 7.0 & stronger \\
\hline 76 & 28-29 JUN 2001 & 6.35 & 12.05 & 151.1 & 49.33 & 8.0 & weaker \\
\hline 77 & 17-18 JUL 2003 & 9.45 & 12.45 & 151.1 & 51.78 & 10.0 & weaker \\
\hline 78 & 28-29 AUG 2013 & 2.95 & 12.15 & 149.7 & 59.22 & 8.0 & stronger \\
\hline 79 & 22-23 AUG 2012 & -7.75 & 12.35 & 149.1 & 75.72 & 7.5 & weaker \\
\hline 80 & 22-23 AUG 2003 & 6.95 & 13.35 & 148.9 & 71.72 & 9.0 & stronger \\
\hline 81 & 20-21 AUG 2004 & -7.95 & 14.45 & 148.6 & 69.73 & 8.0 & stronger \\
\hline 82 & 27-28 JUL 2003 & 11.65 & 12.75 & 148.0 & 42.85 & 8.5 & weaker \\
\hline 83 & 30 SEP -01 OCT & -7.85 & 12.35 & 147.7 & 71.24 & 5.5 & stronger \\
\hline
\end{tabular}


2003

\begin{tabular}{llllllll}
\hline 84 & 08-09 AUG 2016 & -1.35 & 12.75 & 147.6 & 34.62 & 13.5 & weaker \\
\hline 85 & 05-06 AUG 2007 & -4.45 & 13.85 & 147.1 & 61.39 & 14.5 & stronger \\
\hline 86 & $\begin{array}{l}\text { 31 MAY - 01 JUN } \\
\text { 2010 }\end{array}$ & -5.85 & 12.35 & 146.8 & 74.64 & 9.0 & stronger \\
\hline 87 & 08-09 AUG 2019 & -0.55 & 12.85 & 146.6 & 42.99 & 9.0 & stronger \\
\hline 88 & 06-07 JUN 2005 & 10.35 & 13.85 & 146.5 & 47.85 & 10.5 & weaker \\
\hline 89 & 01-02 AUG 2007 & 8.25 & 15.95 & 146.5 & 43.98 & 7.5 & weaker \\
\hline 90 & 01-02 SEP 2007 & 5.05 & 16.25 & 146.4 & 64.52 & 5.0 & stronger \\
\hline 91 & 18-19 SEP 2006 & -2.75 & 15.85 & 146.0 & 36.85 & 10.5 & stronger \\
\hline 92 & 08-09 OCT 2008 & -7.85 & 12.95 & 145.9 & 76.41 & 4.5 & stronger \\
\hline 93 & 04-05 JUL 2000 & 5.45 & 16.35 & 145.4 & 45.79 & 6.5 & weaker \\
\hline 94 & 05-06 JUL 2001 & -7.55 & 12.95 & 145.2 & 46.90 & 12.5 & weaker \\
\hline 95 & 02-03 JUL 2004 & 12.55 & 13.85 & 144.7 & 54.87 & 6.5 & weaker \\
\hline 96 & 23-24 AUG 2011 & -7.35 & 12.85 & 143.6 & 61.21 & 5.0 & weaker \\
\hline 97 & 06-07 AUG 2011 & -6.55 & 15.65 & 141.4 & 63.31 & 9.0 & stronger \\
\hline 98 & 06-07 JUL 2005 & -3.95 & 15.05 & 140.5 & 42.26 & 9.5 & stronger \\
\hline 99 & 28-29 AUG 2011 & -7.95 & 15.65 & 139.8 & 65.46 & 5.5 & weaker \\
\hline 100 & 02-03 JUL 2017 & 9.85 & 15.15 & 138.7 & 29.23 & 12.0 & stronger \\
\hline & & & Mean & 168.4 & 57.8 & 9.8 & \\
\hline & & Dev & 28.8 & 13.5 & 3.1 & \\
\hline & & & & & & \\
\hline 94
\end{tabular}

Table 2. Confirmation of high rainfall event impacts from other sources 


\begin{tabular}{|c|c|c|}
\hline Event & Date & Source \& Relevant Event Information \\
\hline \multirow[t]{3}{*}{1} & \multirow{3}{*}{$\begin{array}{l}20- \\
21 \\
\text { AUG } \\
2019\end{array}$} & $\begin{array}{l}\text { FEWSNET - Abundant rains during the weeks have resulted in flooding in western } \\
\text { Niger and central Mali. }\end{array}$ \\
\hline & & $\begin{array}{l}\text { CRED EM-DAT Disaster \# 2019-0394-20 Aug - } 25 \text { Aug } 2019 \text { excessive rainfall } \\
\text { associated with the same system caused flooding in northern Nigeria resulting in } 12 \\
\text { deaths and } 52,500 \text { people affected }\end{array}$ \\
\hline & & $\begin{array}{l}\text { OCHA Reliefweb - Heavy flooding in during the last weeks of August has affected } \\
211,000 \text { people and left } 57 \text { dead in central Niger. }\end{array}$ \\
\hline \multirow[t]{2}{*}{2} & \multirow{2}{*}{$\begin{array}{l}07- \\
08 \\
\text { AUG } \\
2012\end{array}$} & $\begin{array}{l}\text { FEWSNET - a northerly position of the intertropical front is associated with above } \\
\text { average rainfall across Mali and Niger this week. }\end{array}$ \\
\hline & & $\begin{array}{l}\text { OCHA Reliefweb - Heavy August rains responsible for flooding in the southern } \\
\text { regions of Mali affecting over } 9,000 \text { people }\end{array}$ \\
\hline \multirow[t]{3}{*}{3} & \multirow{3}{*}{$\begin{array}{l}26- \\
27 \\
\text { AUG } \\
2007\end{array}$} & FEWSNET - excessively heavy rainfall resulted in flooding that inundated crops. \\
\hline & & $\begin{array}{l}\text { CRED EM-DAT Disaster \# 2007-0305 - } 26 \text { Jul - } 10 \text { Oct } 2007 \text { excessive rainfall } \\
\text { caused flooding in Burkina Faso resulting in } 52 \text { deaths and } 121,043 \text { people affected }\end{array}$ \\
\hline & & $\begin{array}{l}\text { DREF Bulletin MDRBFO04 - Heavy rains in Burkina Faso since beginning of August } \\
2007 \text { have led to flooding, marooned villages, and extensive damage to houses and } \\
\text { infrastructure. }\end{array}$ \\
\hline \multirow[t]{2}{*}{4} & \multirow[t]{2}{*}{$\begin{array}{l}06- \\
07 \\
\text { AUG } \\
2001\end{array}$} & $\begin{array}{l}\text { Adeoye et al. (2009): Jigawa flood and windstorm resulted in } 6 \text { deaths and 450,150 } \\
\text { people displaced, while the Kano flood and wind storm resulted in } 27 \text { deaths and } \\
20,445 \text { people displaced. }\end{array}$ \\
\hline & & $\begin{array}{l}\text { CRED EM-DAT Disaster \# 2001-0494 - Event help contribute to flash flooding event } \\
\text { in northern Nigeria at the end of the month that resulted in a broken dam/burst bank } \\
\text { resulting in } 200 \text { deaths and } 84,065 \text { people affected. }\end{array}$ \\
\hline \multirow[t]{3}{*}{5} & \multirow{3}{*}{$\begin{array}{l}04- \\
05 \\
\text { AUG } \\
2007\end{array}$} & $\begin{array}{l}\text { FEWSNET - Excessive rainfall across Burkina Faso, Ivory Coast, and Ghana. } \\
\text { Helped to increase Lake Volta lake levels. }\end{array}$ \\
\hline & & $\begin{array}{l}\text { CRED EM-DAT Disaster \# 2007-0305- Event contributed to long term flooding in } \\
\text { Burkina Faso that was reported in the region from } 26 \text { Jul - } 10 \text { Oct } 2007 \text { that } \\
\text { resulted in } 52 \text { deaths and } 121,043 \text { people affected. }\end{array}$ \\
\hline & & $\begin{array}{l}\text { CRED EM-DAT Disaster \# 2007-0389 - Event partially indirectly contributed to long } \\
\text { term flooding in Niger from } 26 \text { Jul - } 10 \text { Oct } 2007 \text { that resulted in } 7 \text { deaths and } \\
57,274 \text { people affected. }\end{array}$ \\
\hline \multirow[t]{2}{*}{6} & \multirow{2}{*}{$\begin{array}{l}23- \\
24 \\
\text { AUG } \\
2019\end{array}$} & $\begin{array}{l}\text { FEWSNET - abundant rains over the past week have resulted in flooding in western } \\
\text { Niger and central Mali. }\end{array}$ \\
\hline & & $\begin{array}{l}\text { CRED EM-DAT Disaster \# 2019-0420 - Flooding from } 24 \text { Aug - } 12 \text { Sep } 2019 \\
\text { affected 6,474 people in Mali. }\end{array}$ \\
\hline 7 & $\begin{array}{l}01- \\
02 \\
\text { SEP } \\
2009\end{array}$ & $\begin{array}{l}\text { CRED EM-DAT Disaster \# 2009-0523 - Partially contributed to the May - Sep } 2009 \\
\text { flooding of region that resulted in } 25 \text { deaths and 20,406 people affected in Mali. }\end{array}$ \\
\hline 8 & $\begin{array}{l}19- \\
20\end{array}$ & $\begin{array}{l}\text { Adeoye et al. (2009): Zamfara flood resulted in buildings and farmland destroyed, } 1 \\
\text { death, and 12,398 people affected, while the Sokoto flood and windstorm resulted in }\end{array}$ \\
\hline
\end{tabular}


JUL houses and farmland destroyed with 0 deaths, but 16,000 people affected.

2001

CRED EM-DAT Disaster \# 2001-0408 - Event contributed to the July 2001 flooding event in northern Nigeria that affected 3,852 people.

$9 \quad 14-\quad$ FEWSNET - Heavy rains in July have increased surface moisture over Wetern

15 Burkina Faso and Mali.

JUL

2007 CRED EM-DAT Disaster \# 2007-0275 - Event contributed to flooding during late July over Mali resulting in 9 deaths and 47,255 people affected.

10 19- FEWSNET - Marked increase in rainfall over Mali and Burkina Faso at this time.

20

JUL

2004

Table 3. Listing of the 4 different types of heavy rainfall events where the duration and peak intensity falls outside of \pm 0.5 standard deviation of the top 100 event mean

\begin{tabular}{|llll|}
\hline $\begin{array}{l}\text { Longer duration/ weaker } \\
\text { peak intensity }\end{array}$ & $\begin{array}{l}\text { Longer duration/ } \\
\text { higher peak } \\
\text { intensity }\end{array}$ & $\begin{array}{l}\text { Shorter duration/ weaker } \\
\text { peak intensity }\end{array}$ & $\begin{array}{l}\text { Shorter duration/ } \\
\text { higher peak } \\
\text { intensity }\end{array}$ \\
\hline 14 events & 5 events & 4 events & 14 events \\
$(3,6,9,28,35,43$, & $(7,14,22,32,62)$ & $(41,76,89,93)$ & $(1,12,13,16,47$, \\
$50,53,55,64,65,70,84$, & & & 61, \\
$94)$ & & $66,69,75,79,81$, \\
& & $83,92,99)$ \\
\hline
\end{tabular}

\section{Figures}




\section{(a) Top 100 maximum total $24-\mathrm{hr}$ rainfall locations}
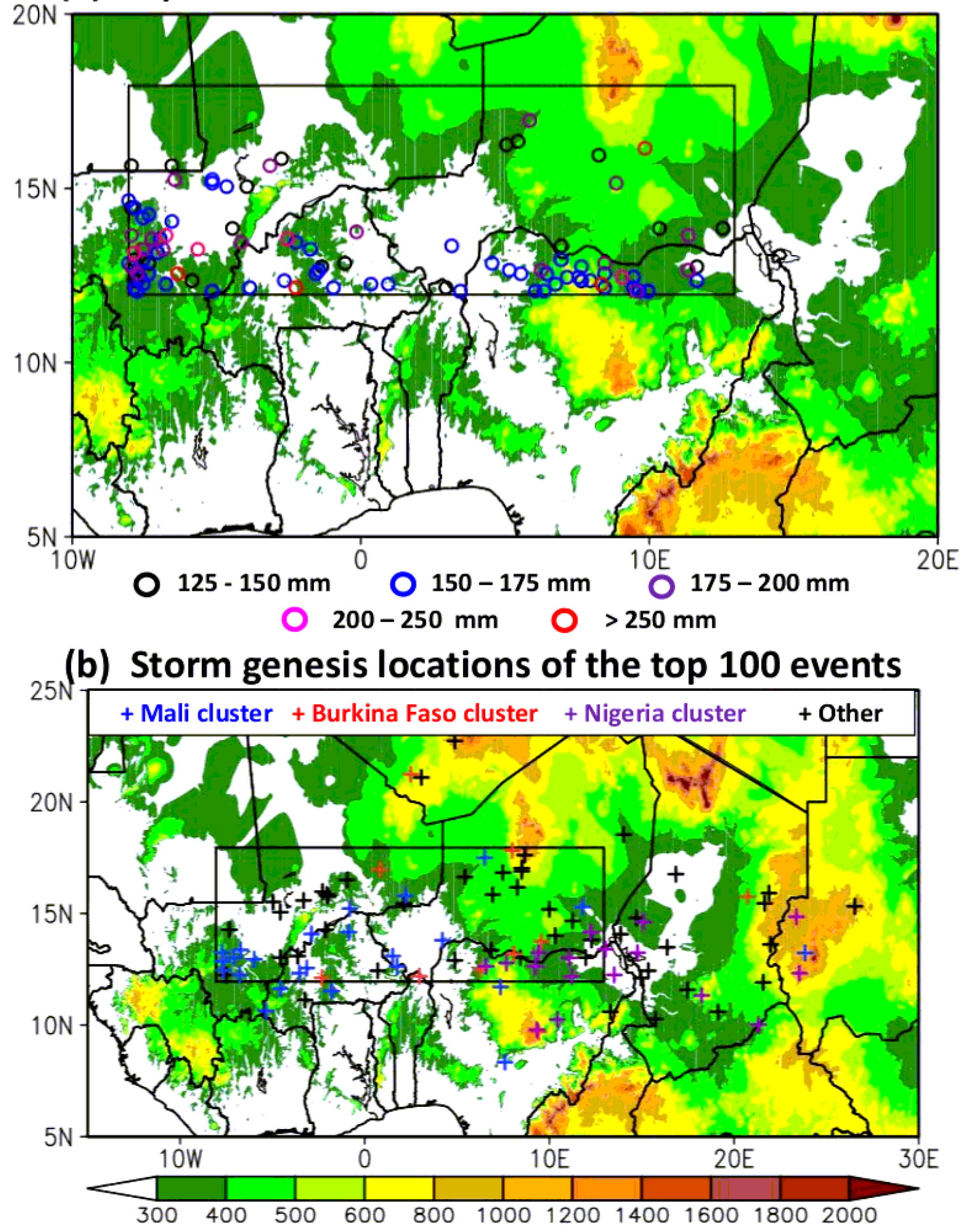

Figure 1

Top 100 event (a) locations of rainfall delivery within the analysis region (circles) and (b) the storm genesis locations (crosses). Color coding in (a) indicates the total rainfall amount, and in (b) the storm genesis locations associated with the Mali (blue), Burkina Faso (red), and northern Nigeria (purple) clusters. Shading in both panels denotes the topography in meters. 

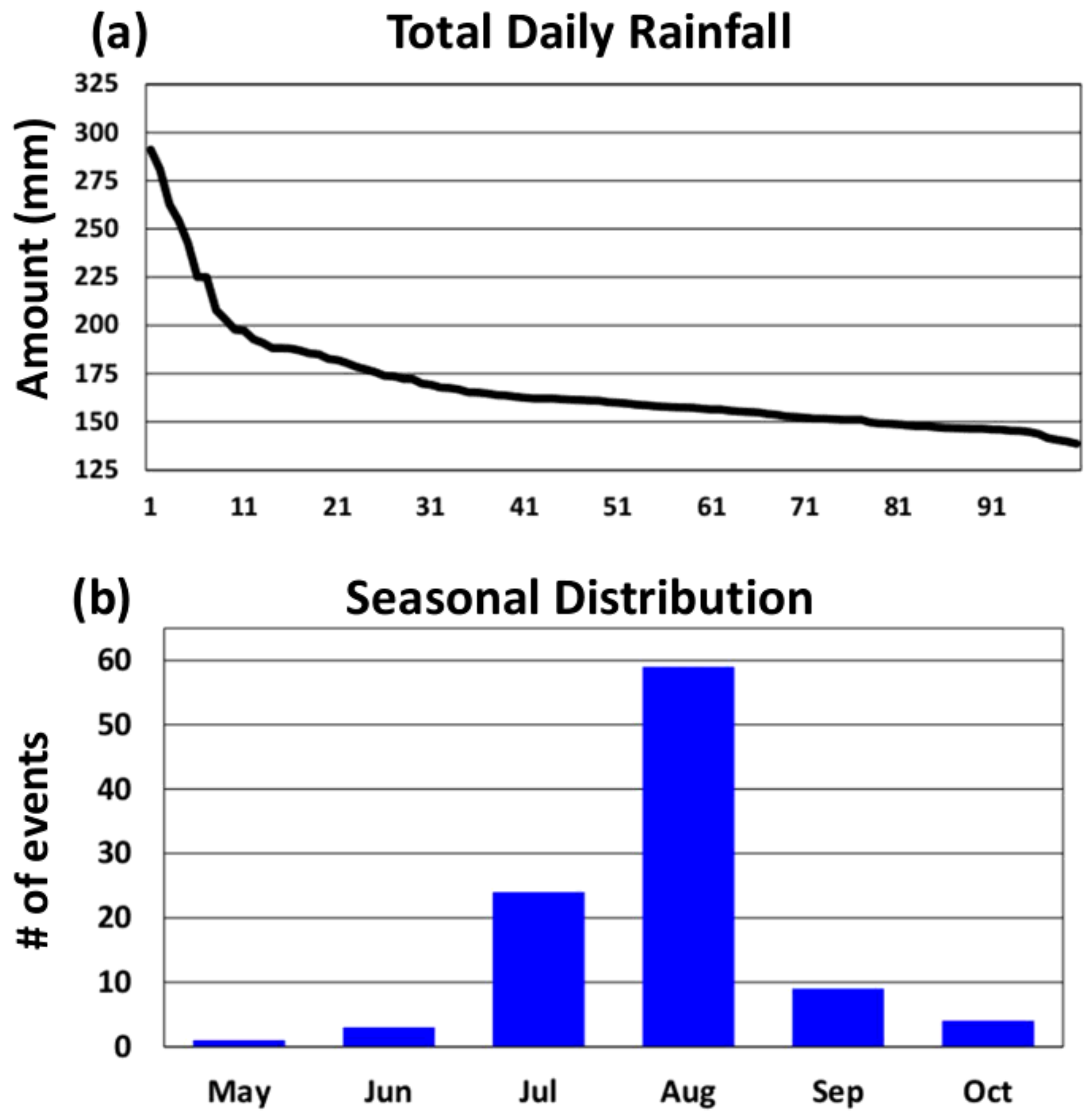

Figure 2

(a) 24-h maximum total rainfall ( $\mathrm{mm}$ ) for the top 100 events shown in Fig. 1, as well as their (b) seasonal distribution. 


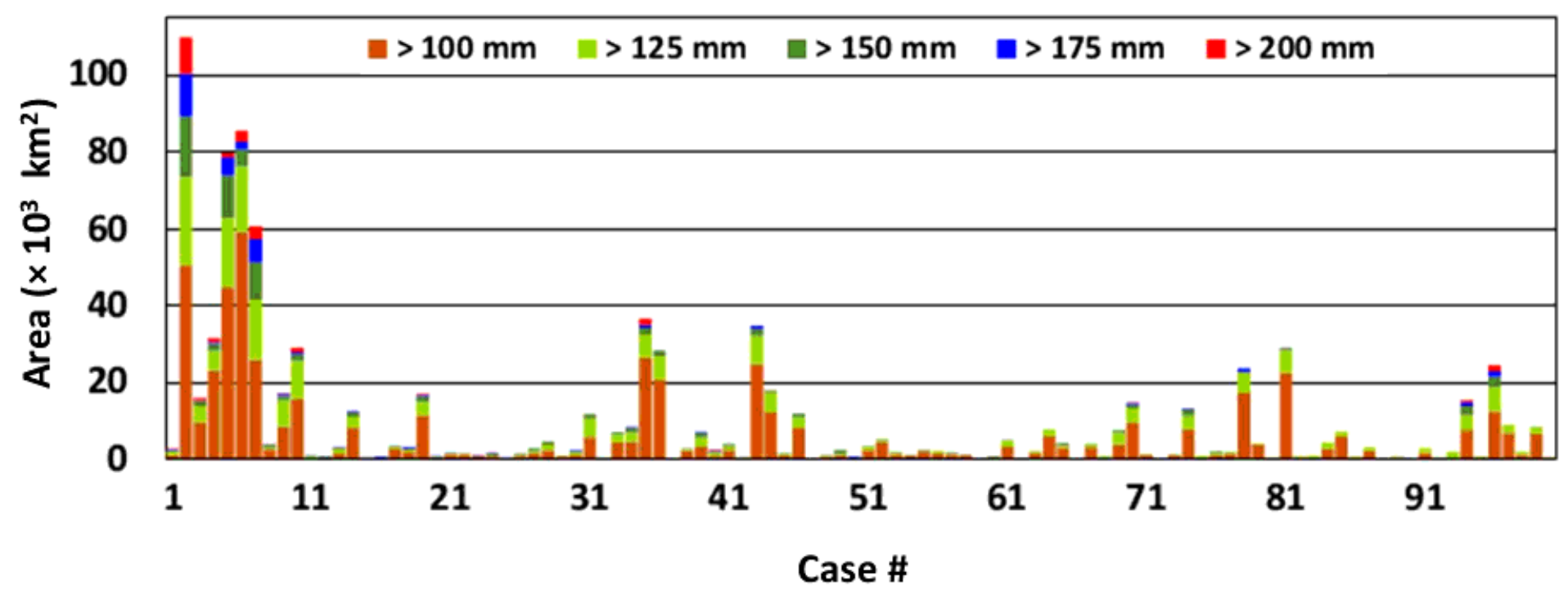

Figure 3

Spatial area of the total $12 Z-12 Z$ daily rainfall $(\times 103 \mathrm{~km} 2)$ for the top 100 events starting at $100 \mathrm{~mm}$ threshold for the events listed in Table 1. 
(a) Clim. 925hPa Wind \& PWAT

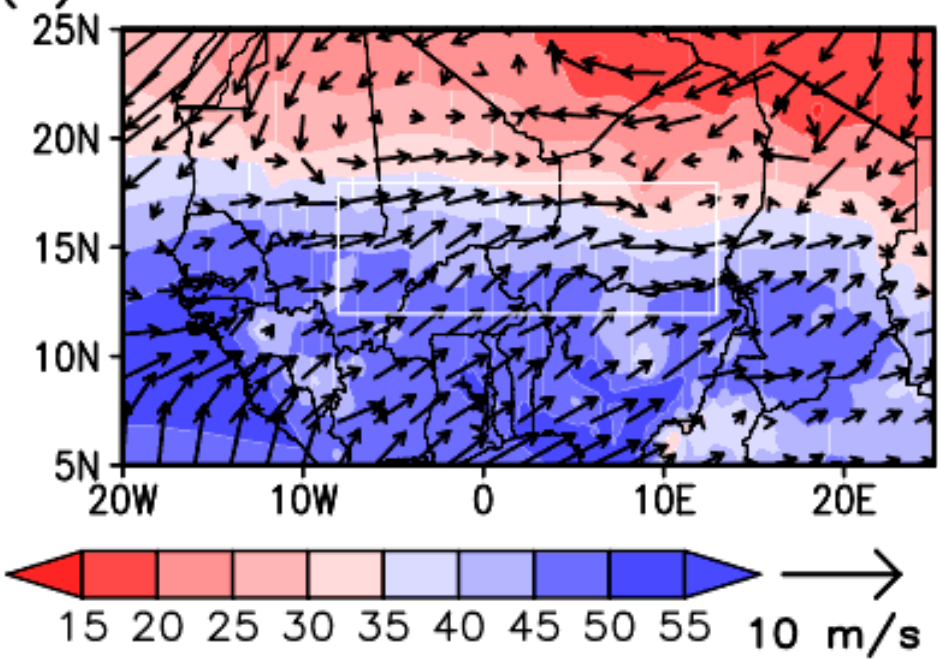

(b) $925 \mathrm{hPa}$ Wind \& PWAT Anom.
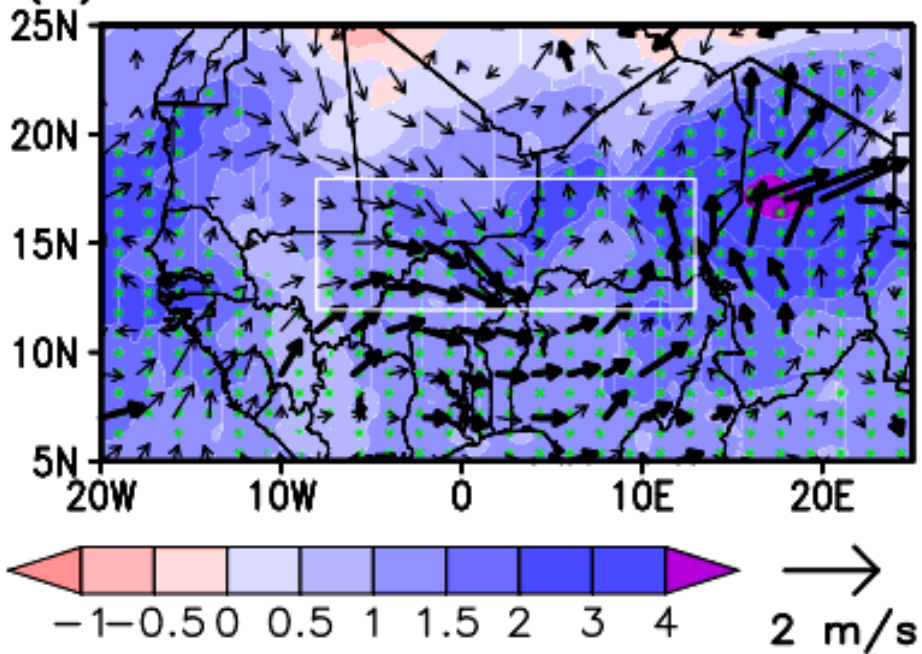

(c) Clim. 600-925 Wind Shear

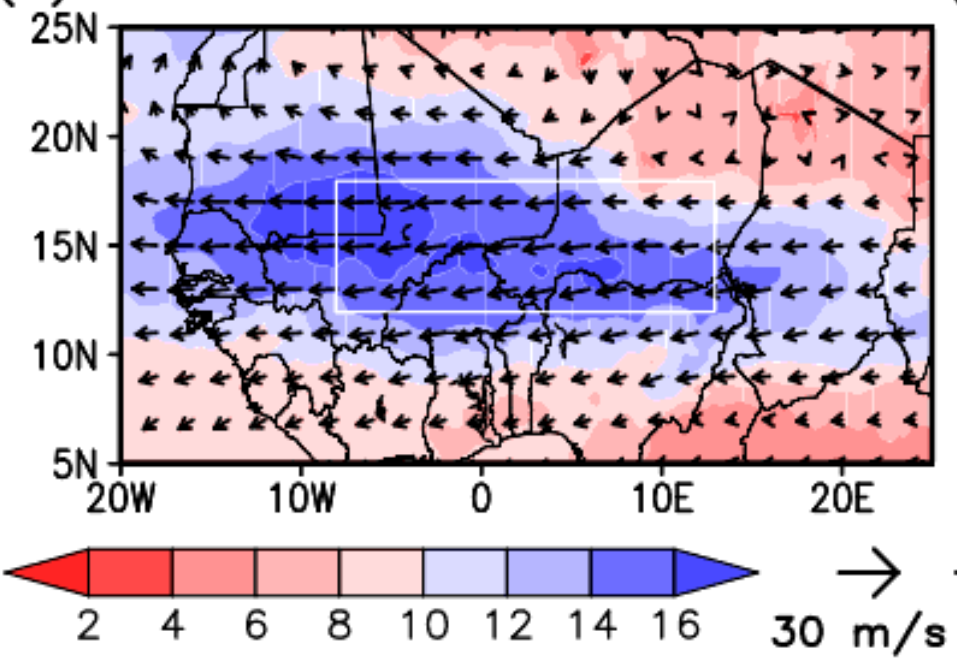

(d) 600-925 Wind Shear Anom.
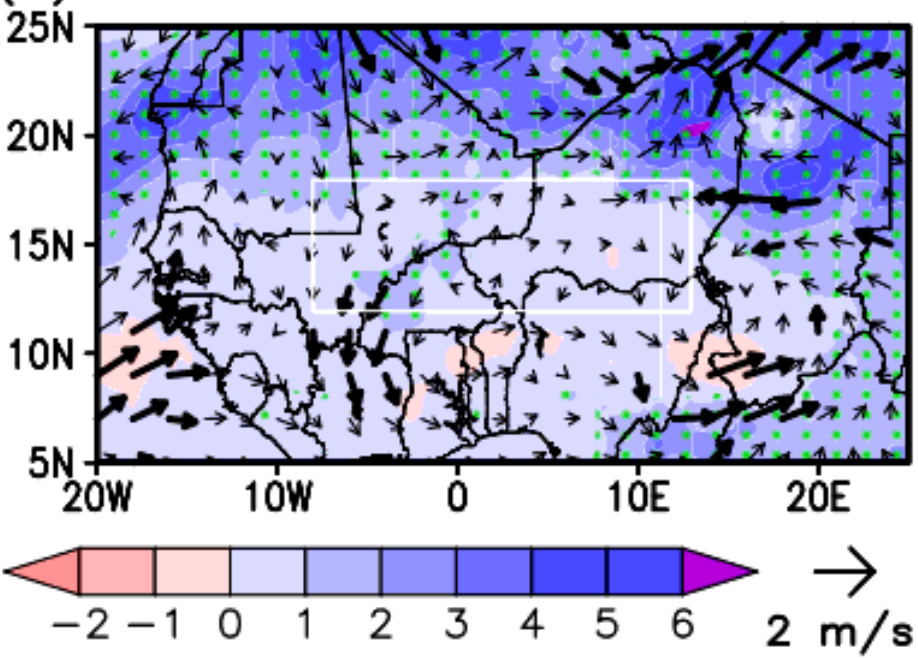

Figure 4

(a) Climatological $12 Z$ precipitable water (PWAT; shaded; $\mathrm{mm}$ ) and $925 \mathrm{hPa}$ horizontal winds (vectors; $\mathrm{m}$ s-1), and their (b) composite anomalies for the top 100 events. (c) Climatological $12 Z 600 \mathrm{hPa}-925 \mathrm{hPa}$ horizontal wind difference (vectors; $\mathrm{m} \mathrm{s}$-1) and magnitude (shaded; $\mathrm{m} \mathrm{s}$-1) and their (d) composite anomalies. Stippling and bold vectors in (b) and (d) indicate values significant at the $95 \%$ level of confidence. Box indicates the defined West African Sahel region. 
(a) CASE01 20-21 AUG2019

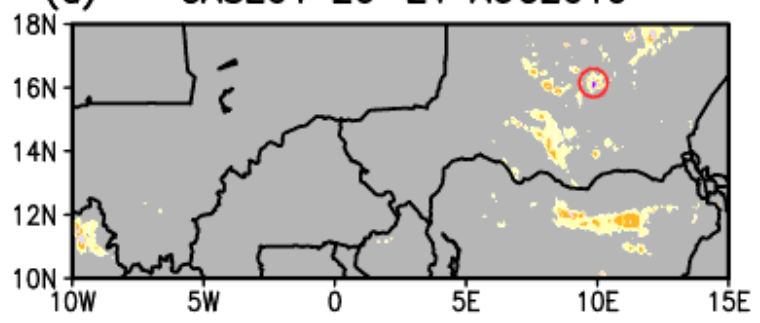

(b) CASE02 07-08 AUG2012

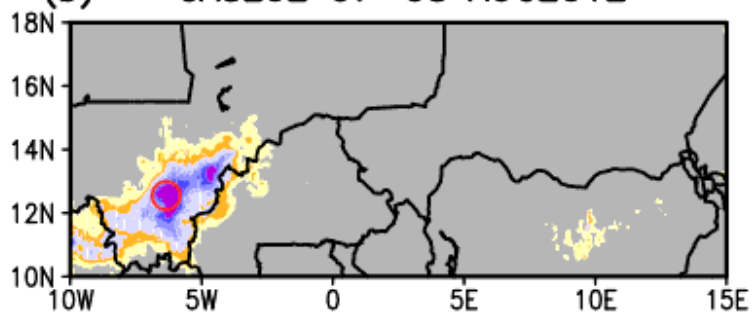

(c) CASE03 26-27 AUG2007

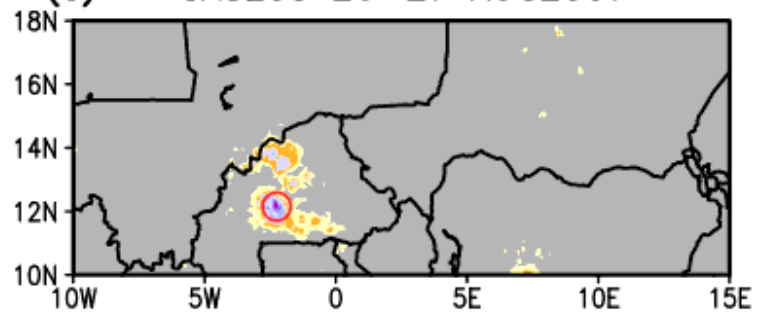

(d) CASE04 06-07 AUG2001

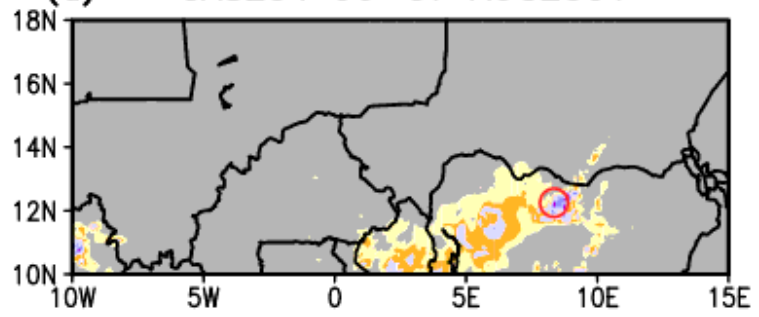

(e) CASE05 04-05 AUG2007
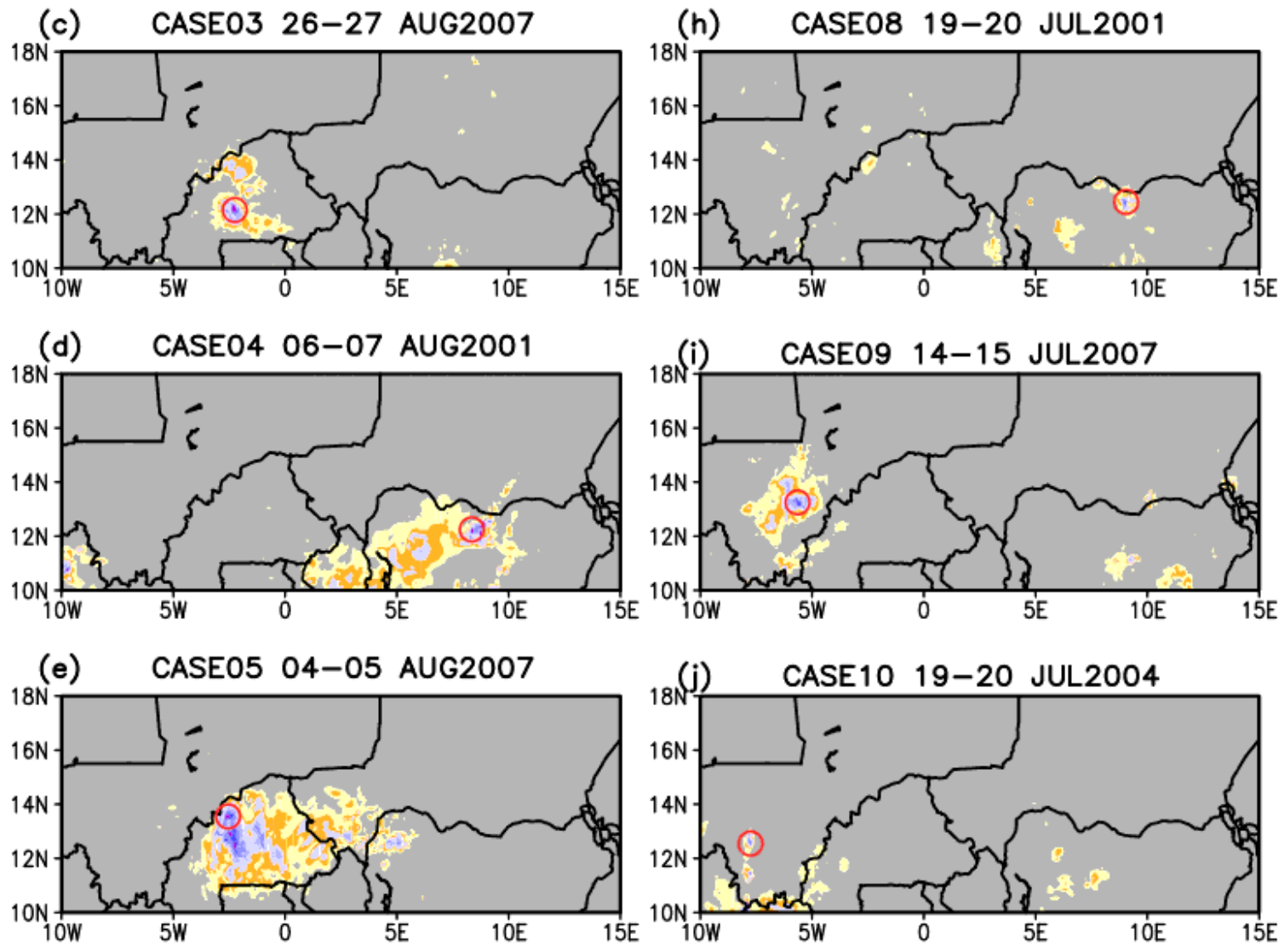

(g) CASE07 01-02 SEP2009

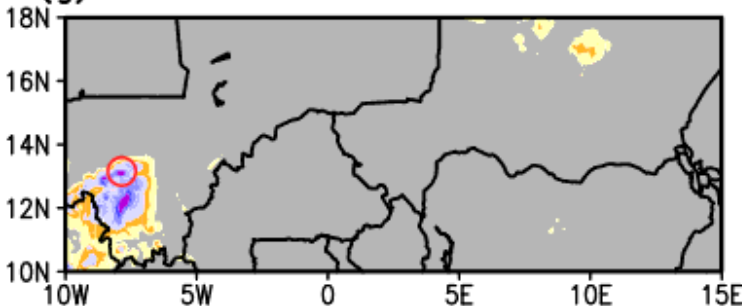

(h) CASE08 19-20 JUL2001

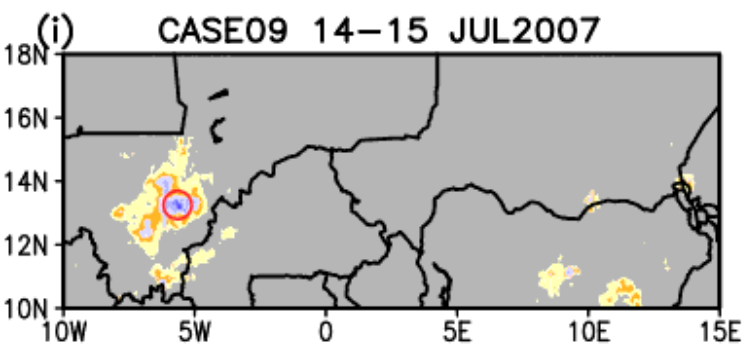

(j) CASE10 19-20 JUL2004

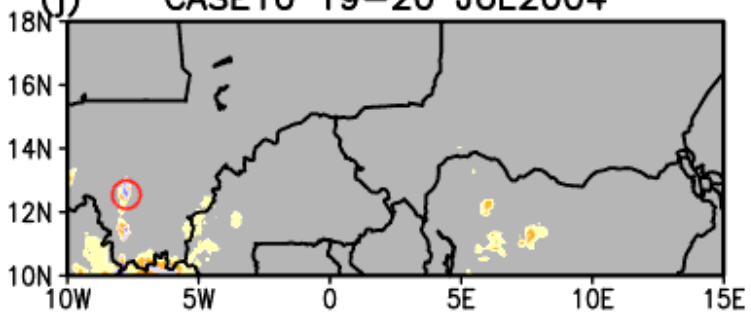

\begin{tabular}{c|c|c|cc|cc|c|c}
\hline & & & & & & & \\
\hline 50 & 75 & 100 & 125 & 150 & 175 & 200
\end{tabular}

Figure 5

Top 10 events, and the corresponding 24-h rainfall totals $(\mathrm{mm})$. Red circle denotes location of maximum 24-h rainfall for each event. 

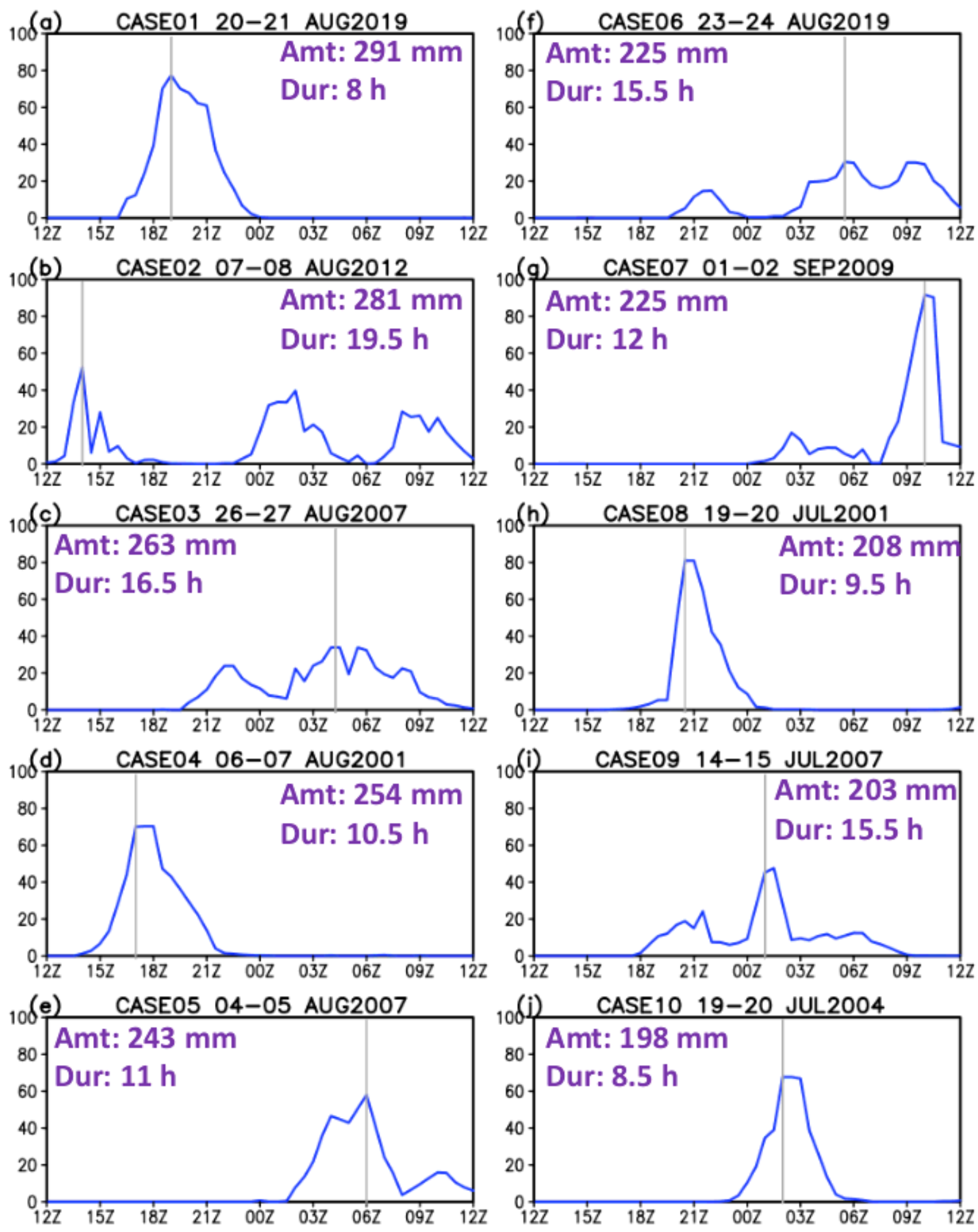

Figure 6

Diurnal cycle of precipitation ( $\mathrm{mm} \mathrm{hr}-1$ ) of the top 10 events. Total $24 \mathrm{~h}$ rainfall amount and duration for each event based on the $10 \mathrm{~mm} /$ day rainfall threshold is provided. Gray line denotes the time of maximum rainfall intensity at the maximum 24 -h total rainfall location. 
(a) Longer duration/weaker peak intensity
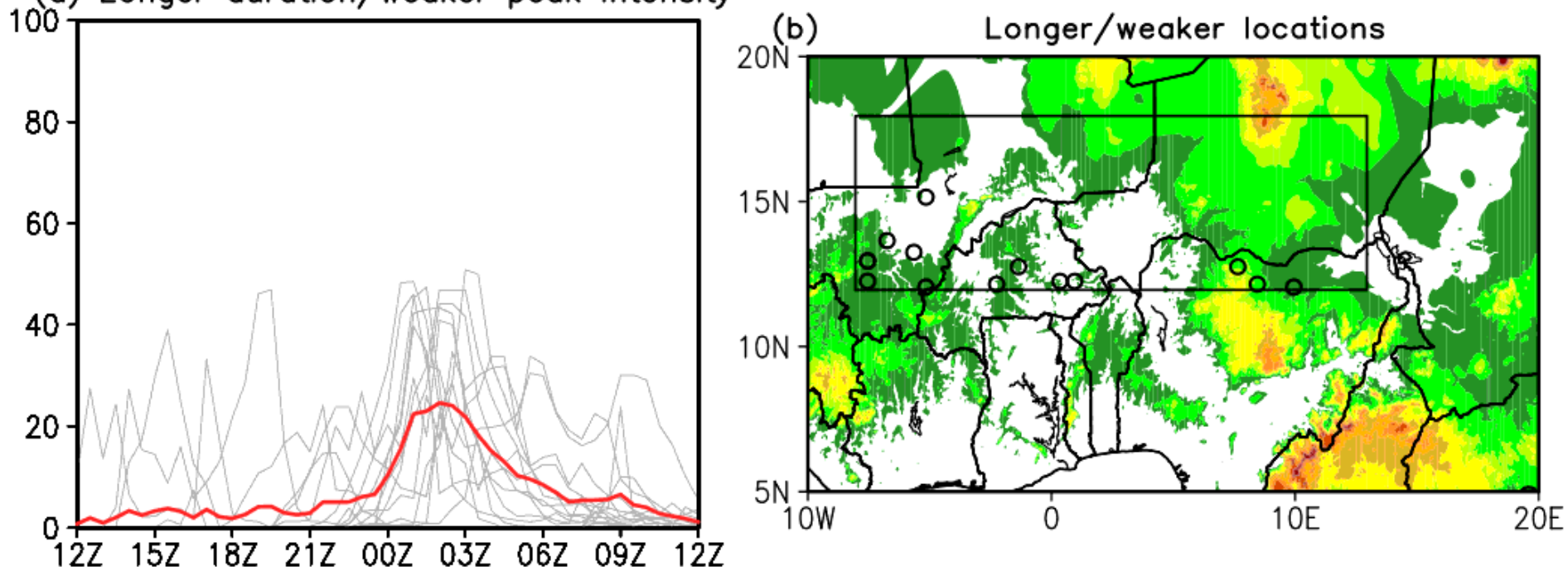

(c) Shorter duration/higher peak intensity
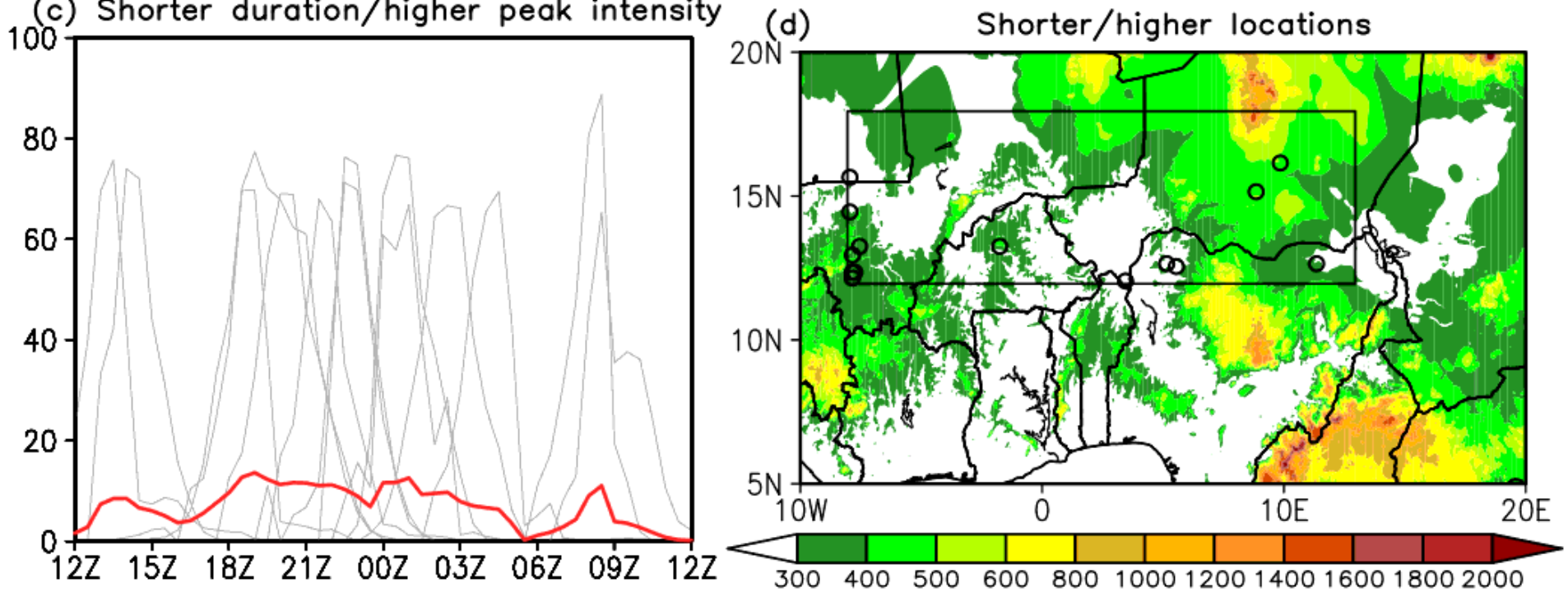

Figure 7

(a) Diurnal cycle of rainfall ( $\mathrm{mm} \mathrm{h-1)}$ of the identified longer duration/weaker peak intensity cases (14 events) and their composite mean (red). (b) Location of the maximum 24-hr rainfall total for each of the 14 events. (c) and (d) are the same as (a) and (b) respectively, but for the identified shorter duration/ higher peak intensity cases (14 events). 


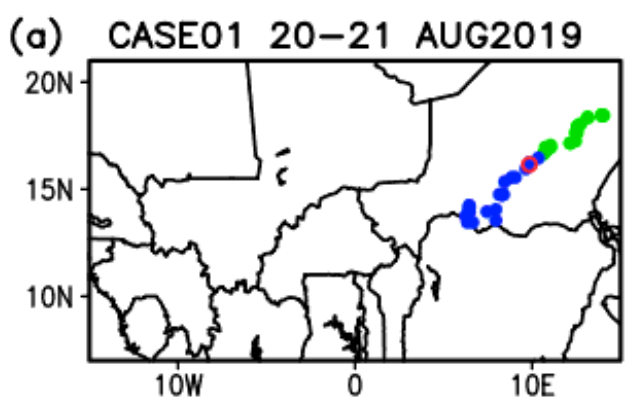

(b) CASE02 07-08 AUG2012

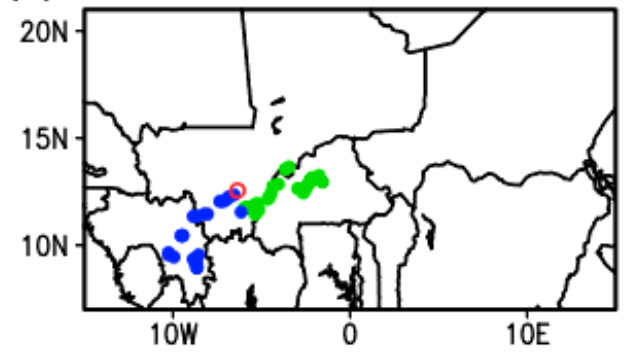

(c) CASEO3 26-27 AUG2007

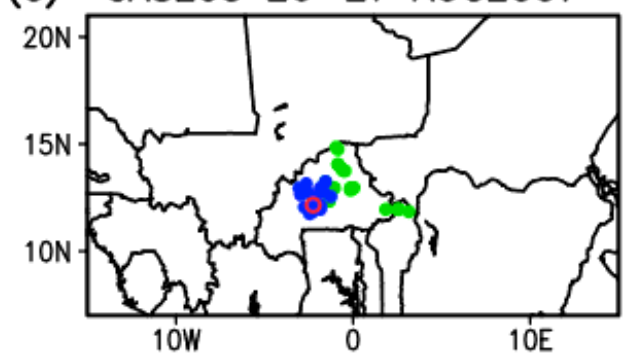

(d) CASE04 06-07 AUG2001

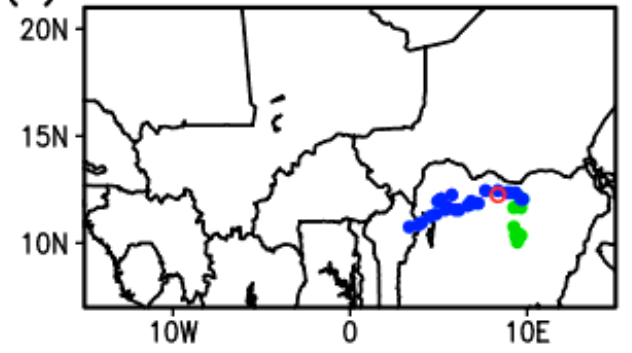

(e) CASEO5 04-05 AUG2007

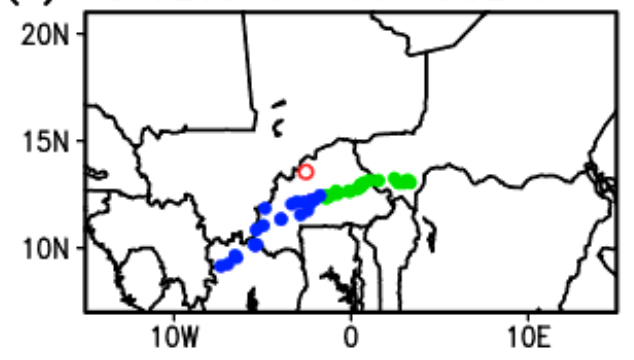

(f) CASEO6 23-24 AUG2019

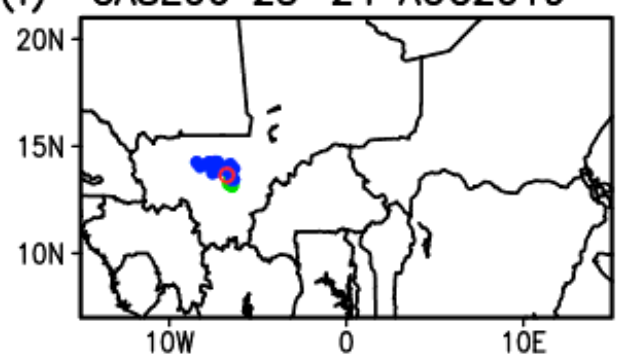

(g) CASE07 01-02 SEP2009

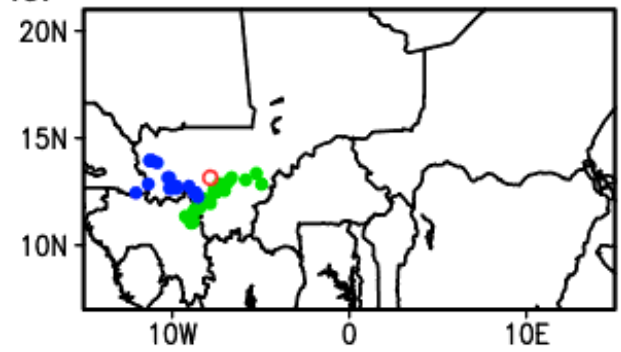

(h) CASE08 19-20 JUL2001

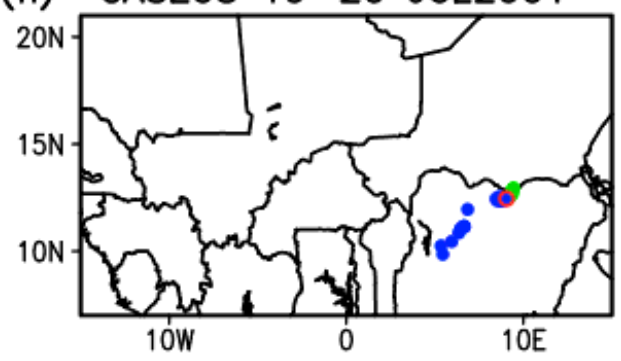

(i) CASEO9 14-15 JUL2007

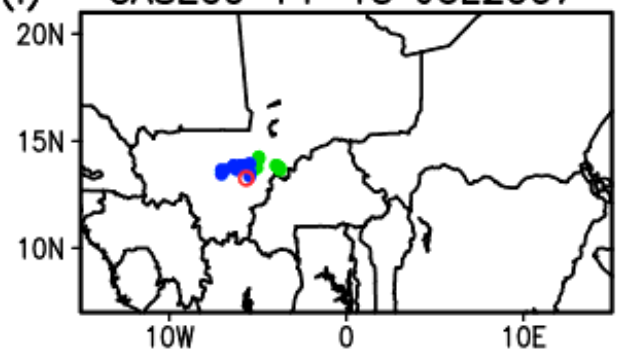

(j) CASE10 19-20 JUL2004

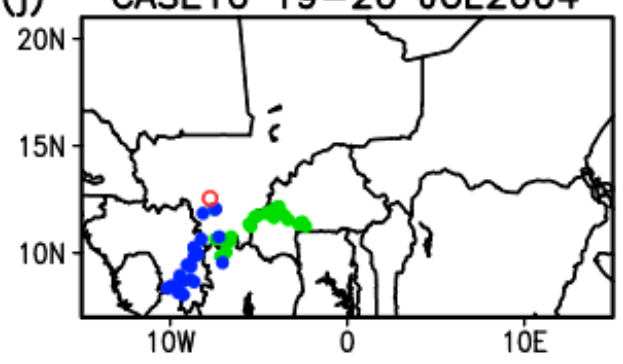

Figure 8

Tracking of the MCS convective core defined by the $100 \mathrm{~mm} /$ day rain shield that traverses the site of maximum 24-h rainfall (red circle) for each event. Green (blue) marks denote location of the convective core for times prior (after) the peak intensity as defined by the gray lines in Fig. 6 . 

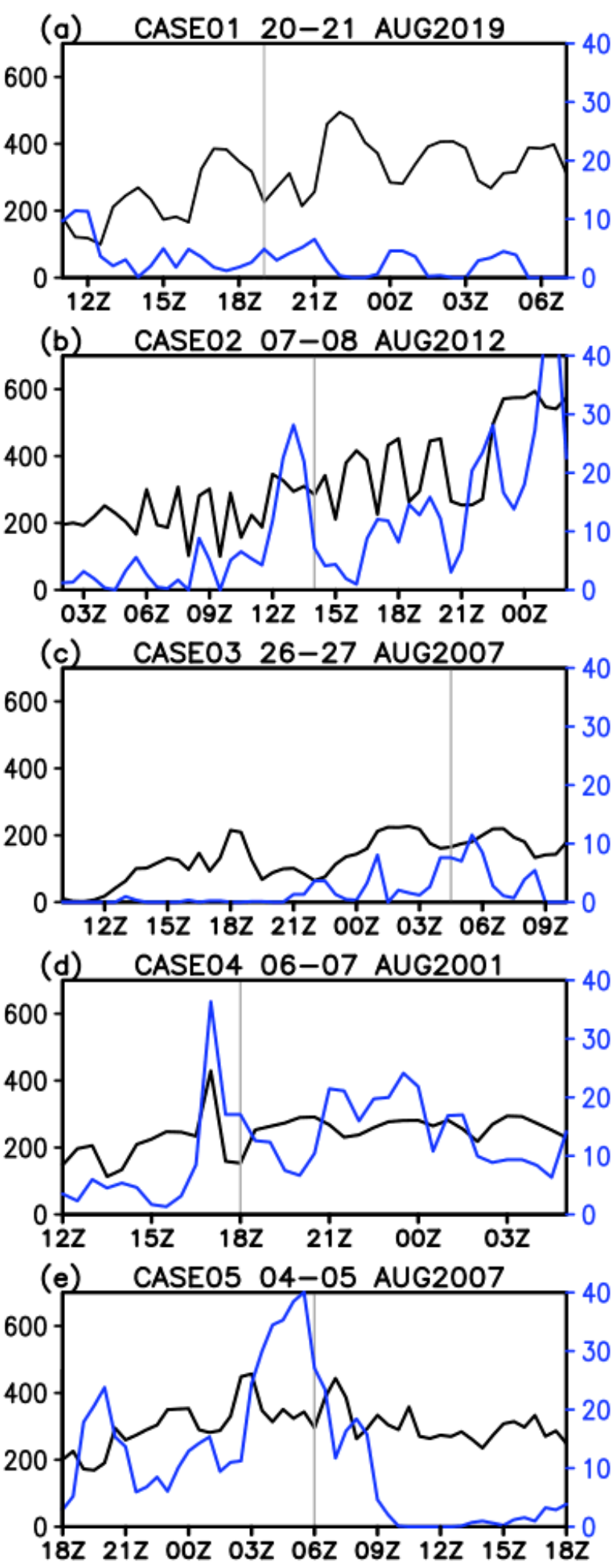
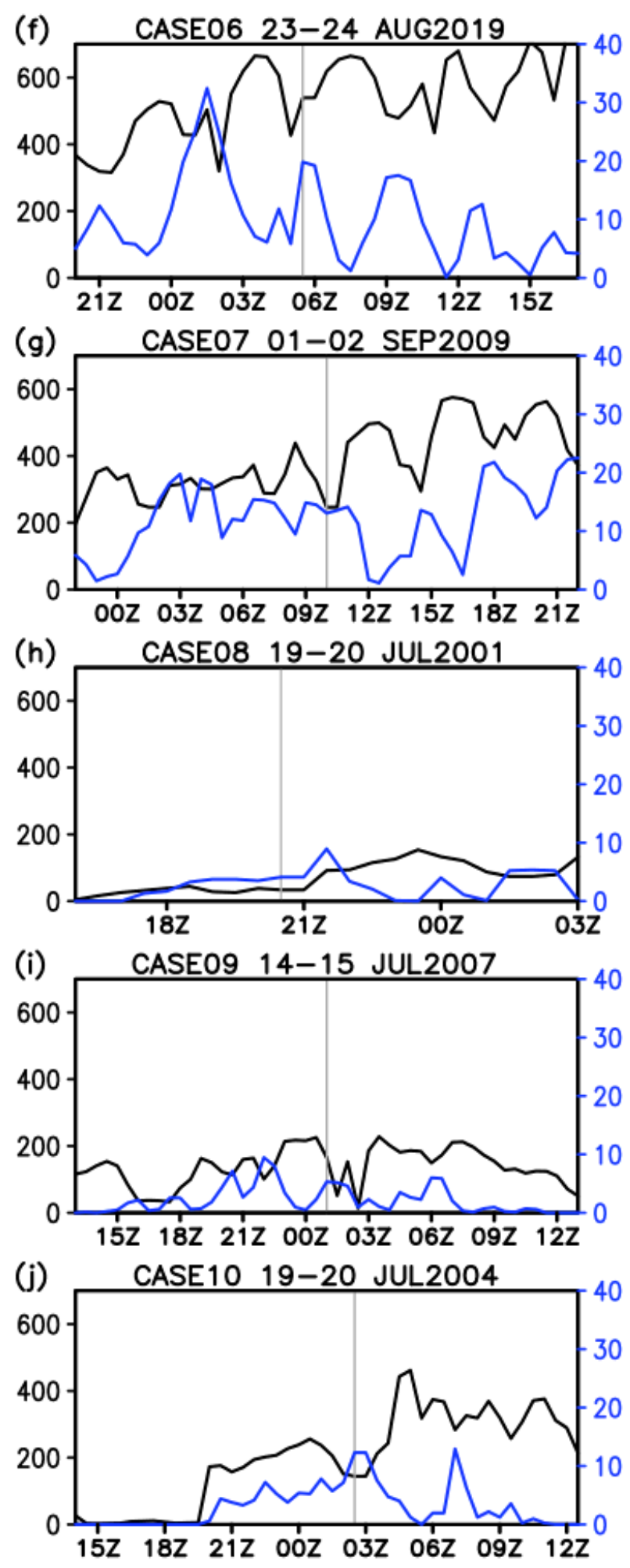

Figure 9

Storm area $(\times 103 \mathrm{~km} 2)$ for the $5 \mathrm{~mm}$ day- 1 (black) and $500 \mathrm{~mm}$ day- 1 (blue) rain shields for the top 10 events. Gray line denotes time of maximum rainfall intensity at the maximum 24 -h total rainfall location. 
(a) CASE01 $18 Z 20$ AUG 2019

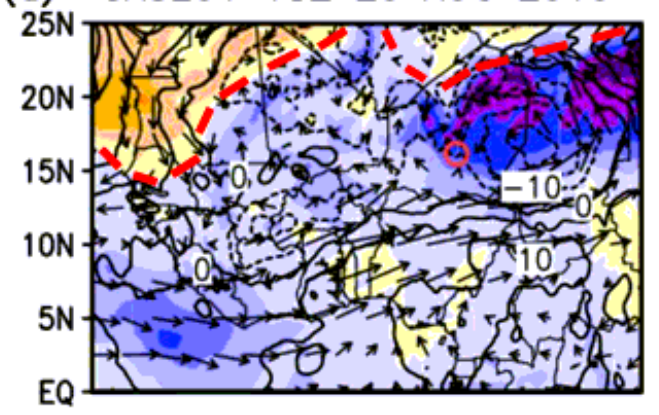

(c) CASEO4 $15 Z$ O6 AUG 2001

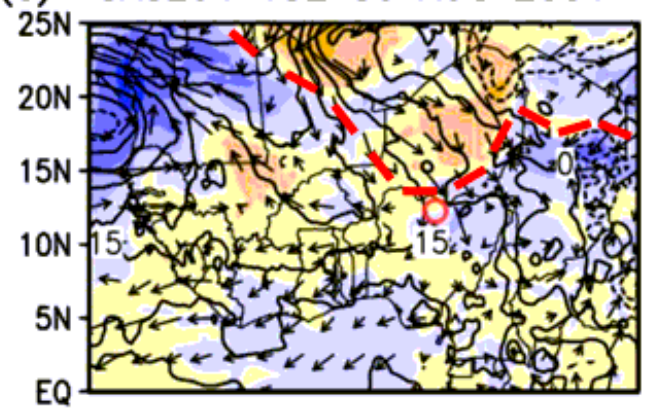

(e) CASE08 15Z 19 JUL 2001

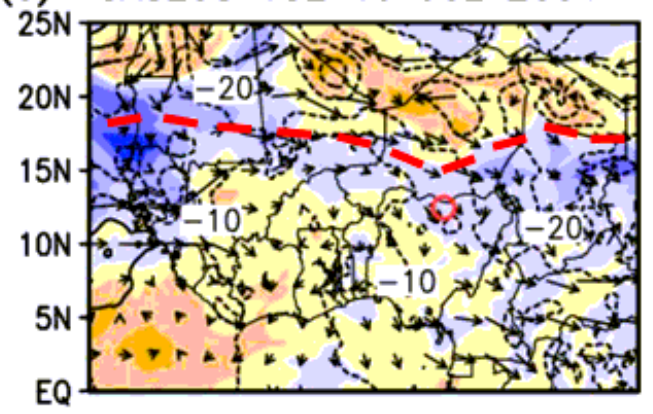

(g) CASE10 02Z 20 JUL 2004
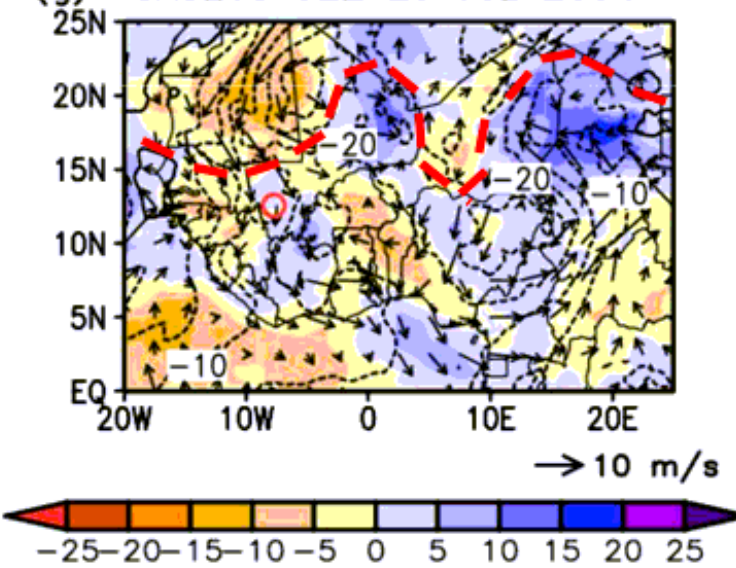

(b) CASEO1 18Z 20 AUG 2019

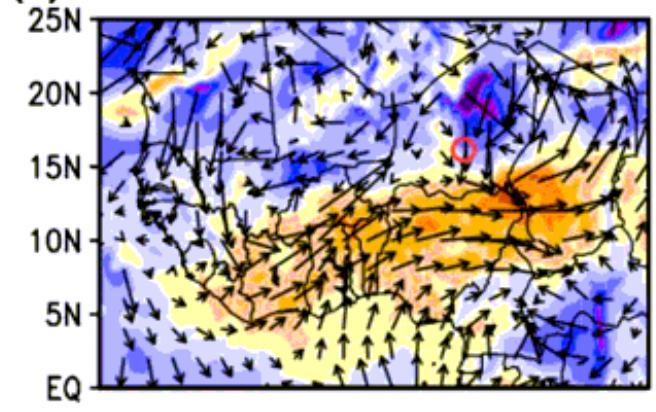

(d) CASEO4 15Z 06 AUG 2001

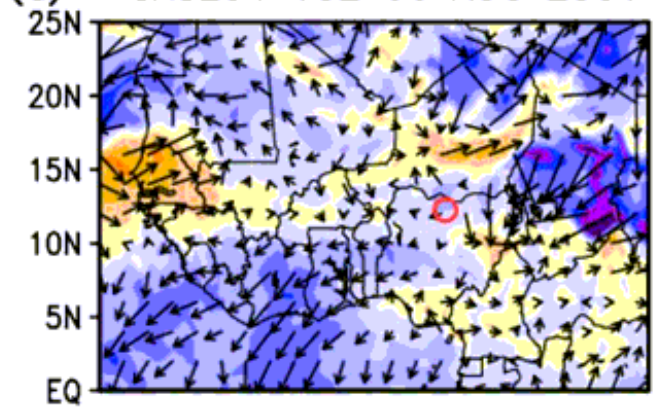

(f) CASE08 15Z 19 JUL 2001

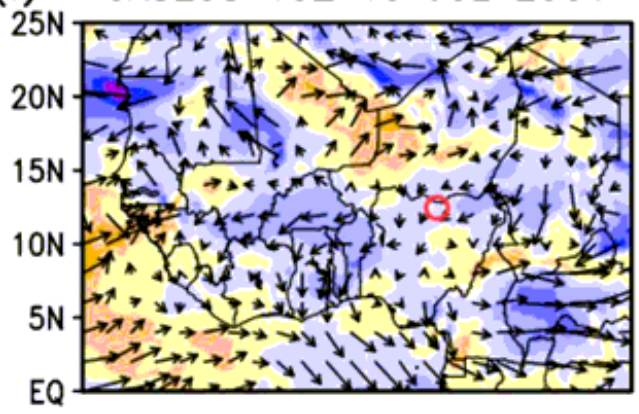

(h) CASE10 02Z 20 JUL 2004
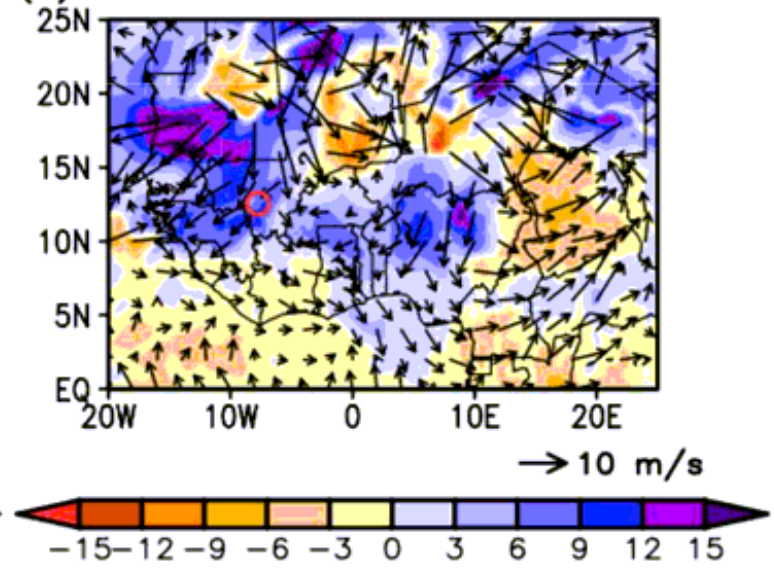

Figure 10

(a) $700 \mathrm{hPa}$ geopotential height (contours; m), $700 \mathrm{hPa}$ wind (vectors; $\mathrm{m} \mathrm{s}-1$ ), and precipitable water (shading; $\mathrm{mm}$ ) anomalies, and (b) $600 \mathrm{hPa}-925 \mathrm{hPa}$ horizontal wind difference (vectors; $\mathrm{m} \mathrm{s}-1$ ) and magnitude (shaded; $m$ s) at a selected time for CASE01. (c) \& (d) similar, but for CASE04. (e) \& (f) similar to (a) \& (b), but for CASE08. (g) \& (h) similar to (a) \& (b), but for CASE10. Red circle denotes the location 
of the event maximum rainfall, while red dashed lined denotes position of the Sahel/tropical Africa dryline boundary as inferred from the $925 \mathrm{hPa}$ specific humidity field.

(a) CASE01 $700 \mathrm{hPa} \mathrm{RV}$

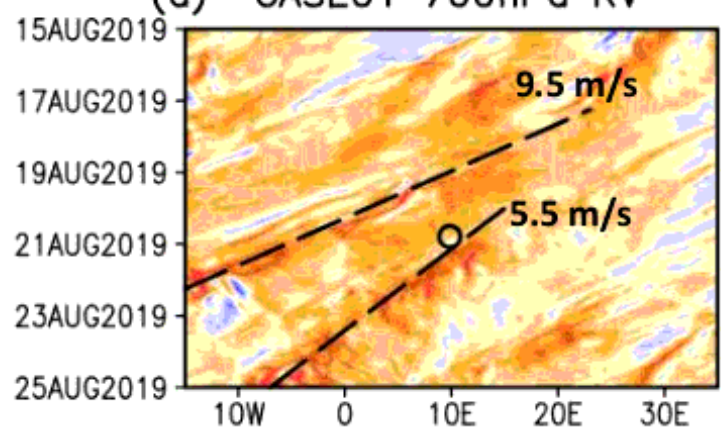

(c) CASE04 $700 \mathrm{hPa} \mathrm{RV}$

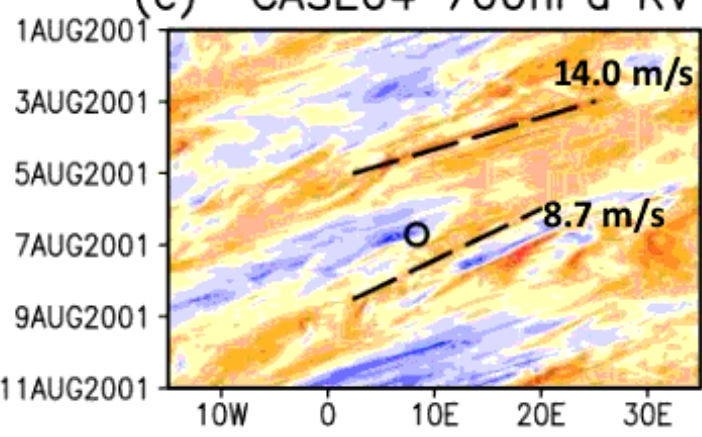

(e) CASE08 $700 \mathrm{hPa}$ RV

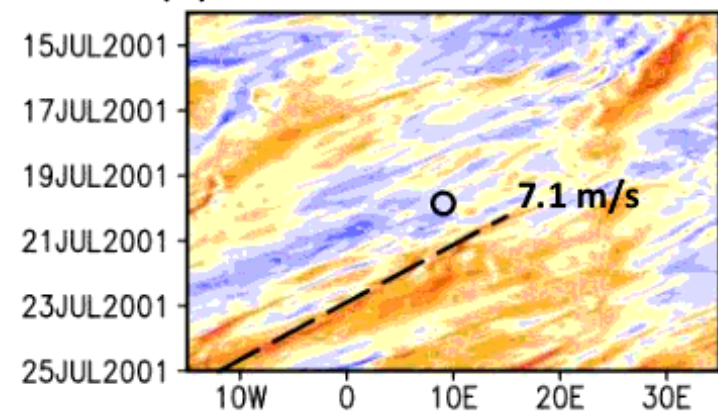

(g) CASE10 700hPa RV

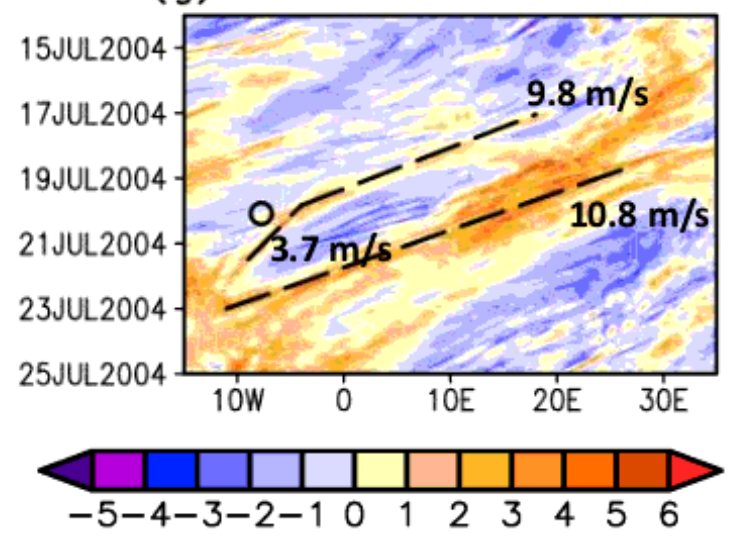

(b) CASE01 PW

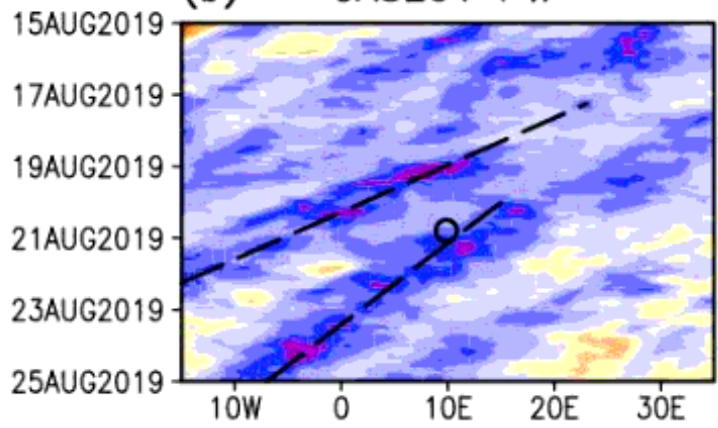

(d) CASEO4 PW

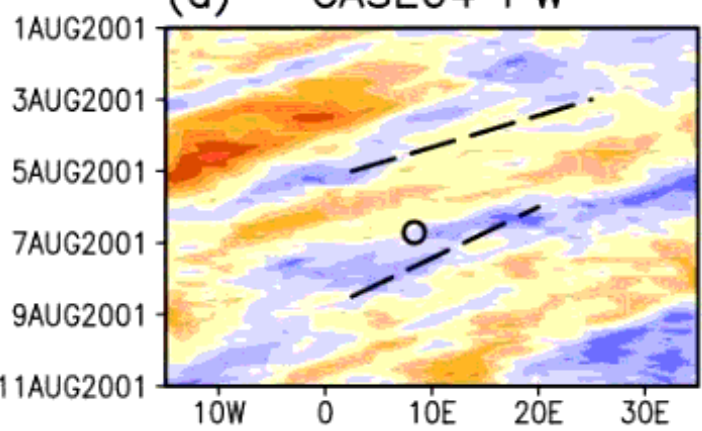

(f) CASE08 PW

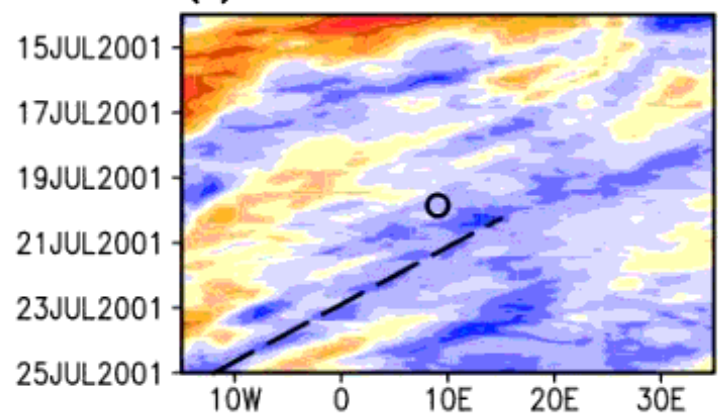

(h) CASE10 PW

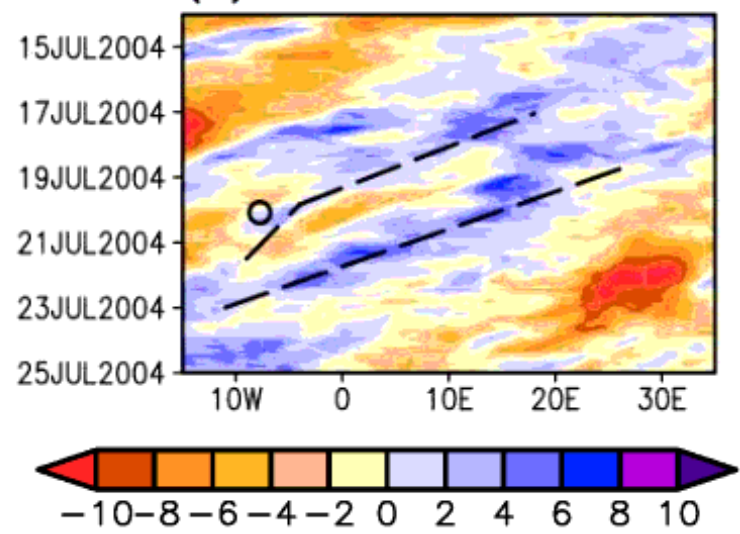

\section{Figure 11}

Hovmöllers of (left column) $700 \mathrm{hPa}$ relative vorticity $\left(\times 10-5 \mathrm{~s}-1\right.$ ) averaged from $10^{\circ} \mathrm{N}-15^{\circ} \mathrm{N}$, and (right column) precipitable water differences from the 2000-2019 climatology $(\mathrm{mm})$ averaged from $10^{\circ} \mathrm{N}-15^{\circ} \mathrm{N}$ for the (a \& b) CASE01, (c \& d) CASE04, (e \& f) CASE08, and ( $\&$ \&) CASE10 events. The circle denotes the 
time and longitude of the peak intensity of the event, while dashed lines denote relevant wave disturbances and their estimated speeds as indicated from the $700 \mathrm{hPa}$ relative vorticity field.

(a) CASEO2 $12 Z 07$ AUG 2012

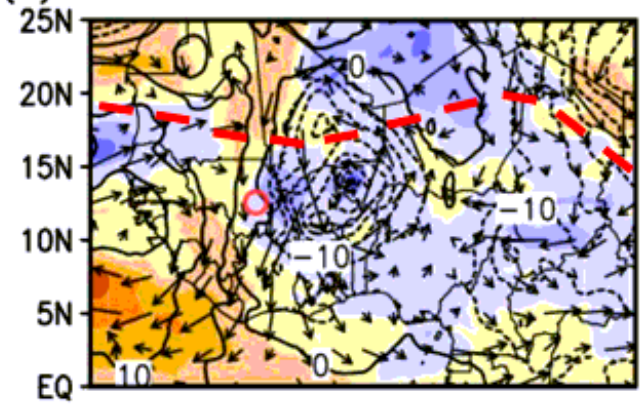

(c) CASE03 OOZ 27 AUG 2007

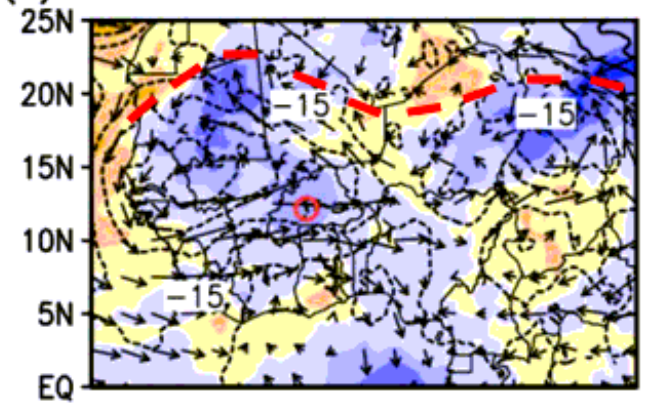

(e) CASE06 O0Z 24 AUG 2019

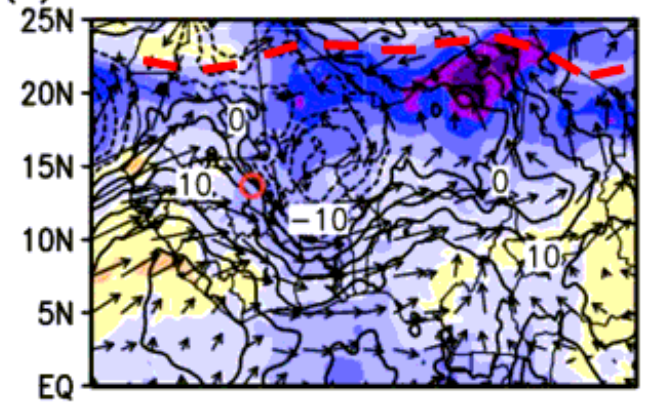

(g) CASEO9 $18 Z 14$ JUL 2007
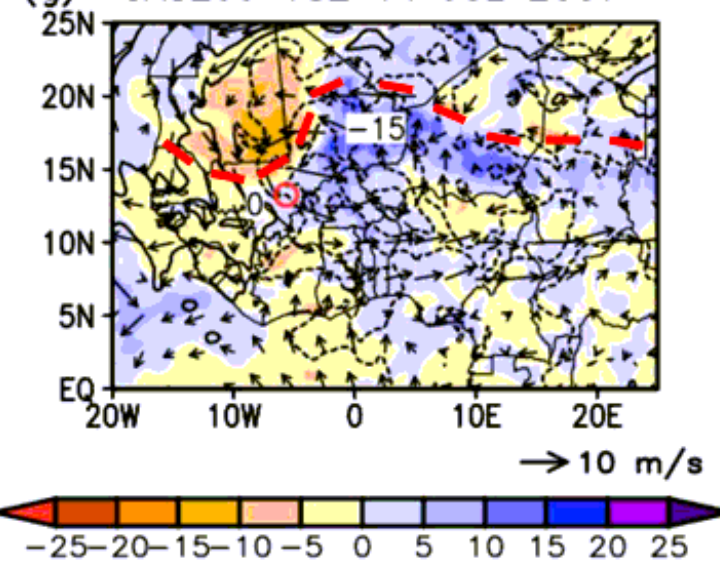

(b) CASE02 $12 Z 07$ AUG 2012

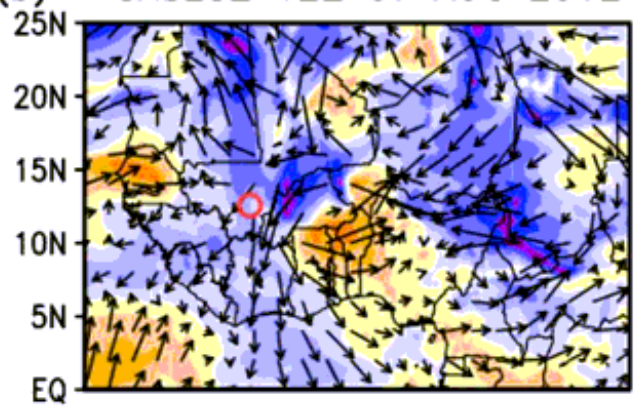

(d) CASEO3 O0Z 27 AUG 2007

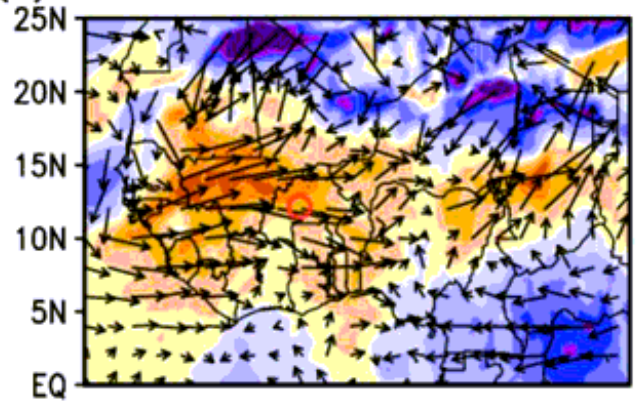

(f) CASE06 O0Z 24 AUG 2019

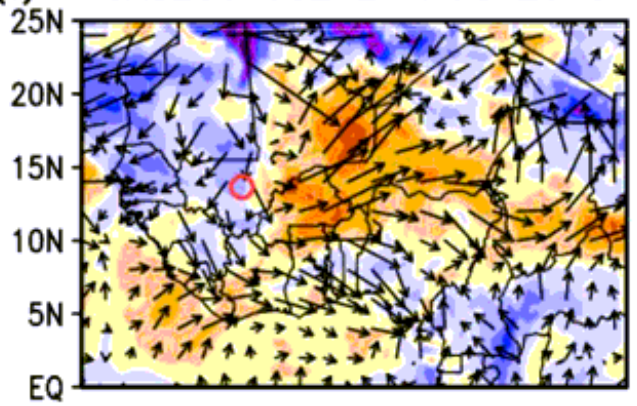

(h) CASEO9 $18 Z 14$ JUL 2007
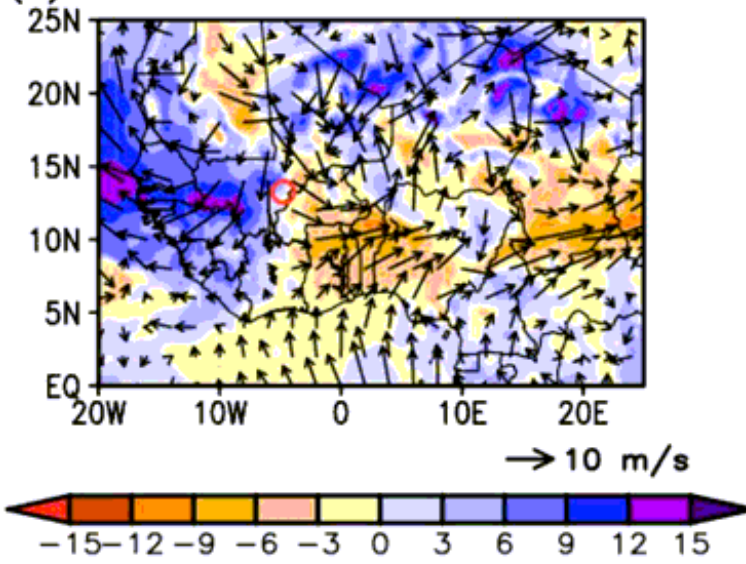

Figure 12

(a) $700 \mathrm{hPa}$ geopotential height (contours; m), $700 \mathrm{hPa}$ wind (vectors; $\mathrm{m} \mathrm{s}-1$ ), and precipitable water (shading; $\mathrm{mm}$ ) anomalies, and (b) $600 \mathrm{hPa}-925 \mathrm{hPa}$ horizontal wind difference (vectors; $\mathrm{m} \mathrm{s}-1$ ) and magnitude (shaded; $m$ s-1) at a selected time for CASE02. (c) \& (d) similar, but for CASE03. (e) \& (f) 
similar to (a) \& (b), but for CASE06. (g) \& (h) similar to (a) \& (b), but for CASE09. Red circle denotes the location of the event maximum rainfall, while red dashed lined denotes position of the Sahel/tropical Africa dryline boundary as inferred from the $925 \mathrm{hPa}$ specific humidity field.

(a) CASE02 $700 \mathrm{hPa} \mathrm{RV}$

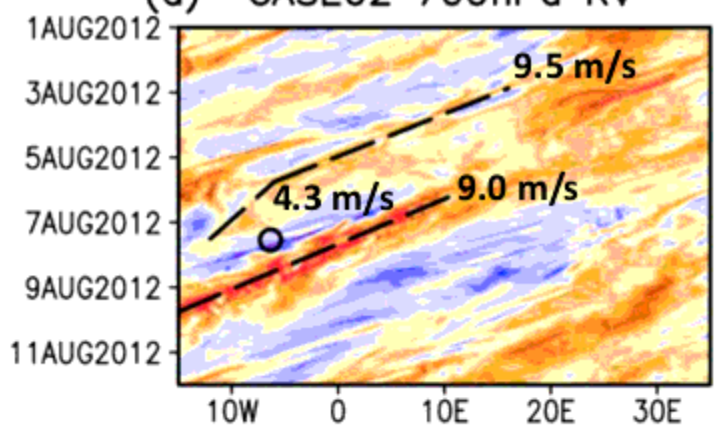

(c) CASE03 $700 \mathrm{hPa}$ RV

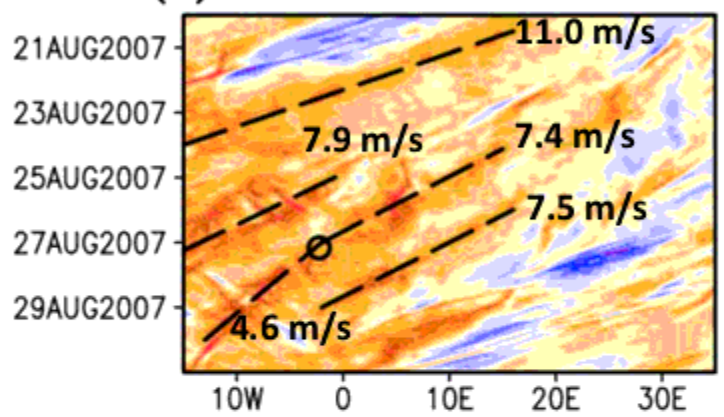

(e) CASE06 $700 \mathrm{hPa} \mathrm{RV}$

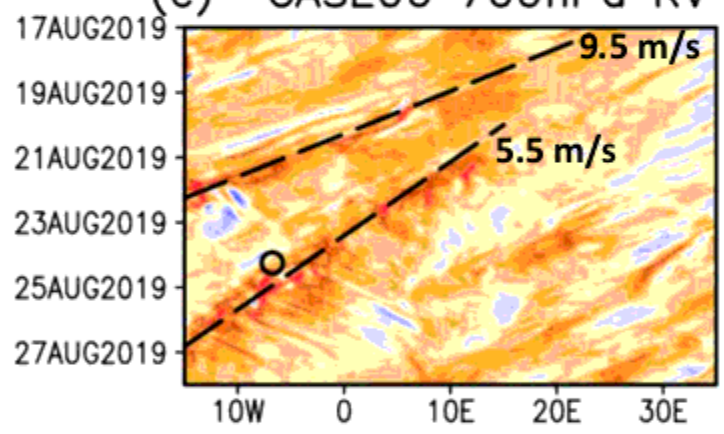

(g) CASEO9 $700 \mathrm{hPa} \mathrm{RV}$

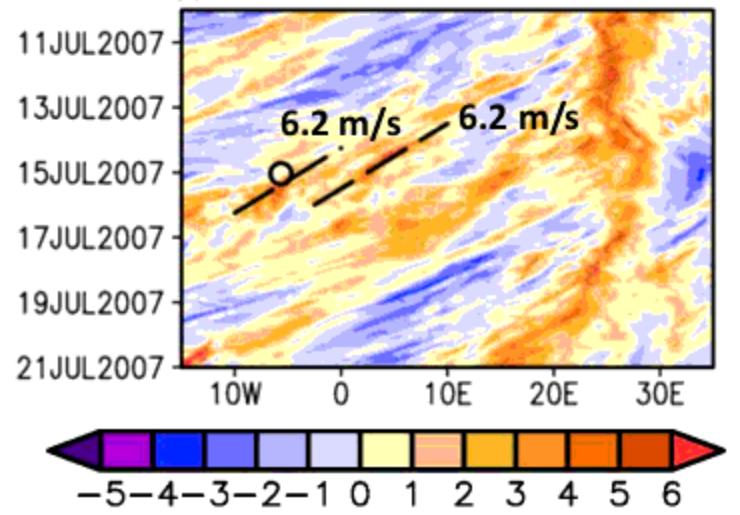

(b) CASE02 PW

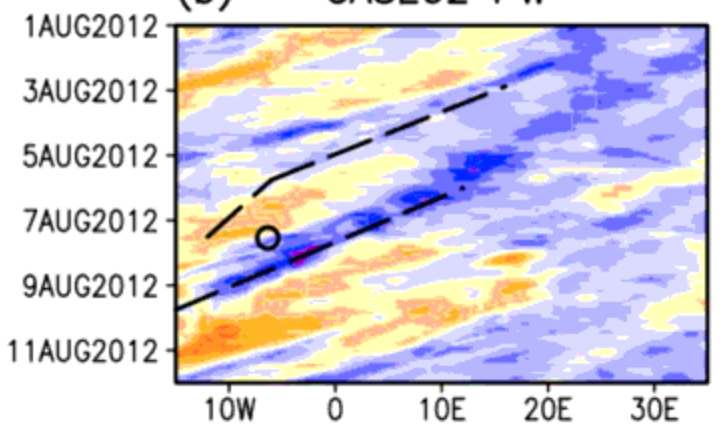

(d) CASE03 PW

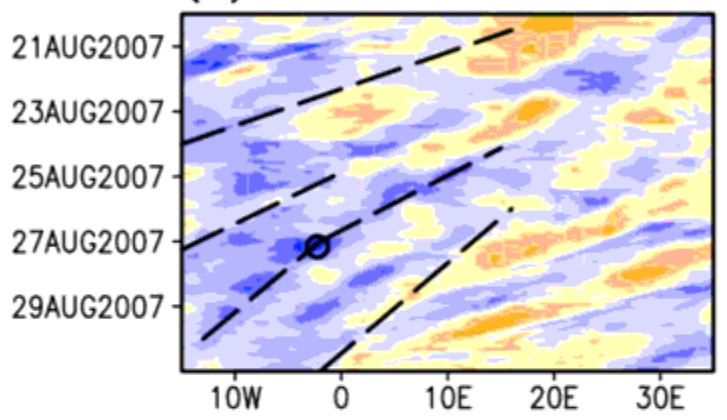

(f) CASEO6 PW

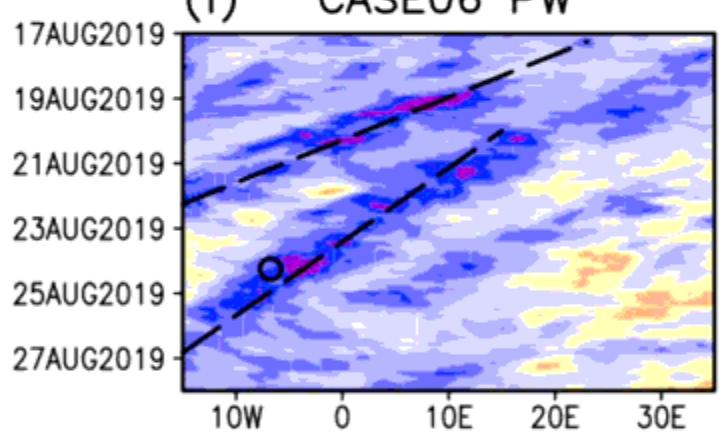

(h) CASEO9 PW

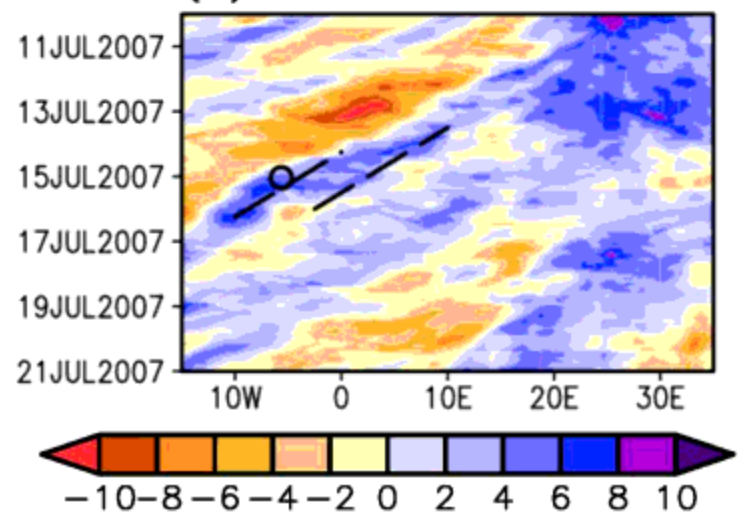

Figure 13

Hovmöllers of (left column) $700 \mathrm{hPa}$ relative vorticity $\left(\times 10-5 \mathrm{~s}-1\right.$ ) averaged from $10^{\circ} \mathrm{N}-15^{\circ} \mathrm{N}$, and (right column) precipitable water differences from the $2000-2019$ climatology $(\mathrm{mm})$ averaged from $10^{\circ} \mathrm{N}-15^{\circ} \mathrm{N}$ 
for the (a \& b) CASE02, (c \& d) CASE03, (e \& f) CASE06, and ( $g$ \& h) CASE09 events. The circle denotes the time and longitude of the peak intensity of the event, while dashed lines denote relevant wave disturbances and their estimated speeds as indicated from the $700 \mathrm{hPa}$ relative vorticity field.
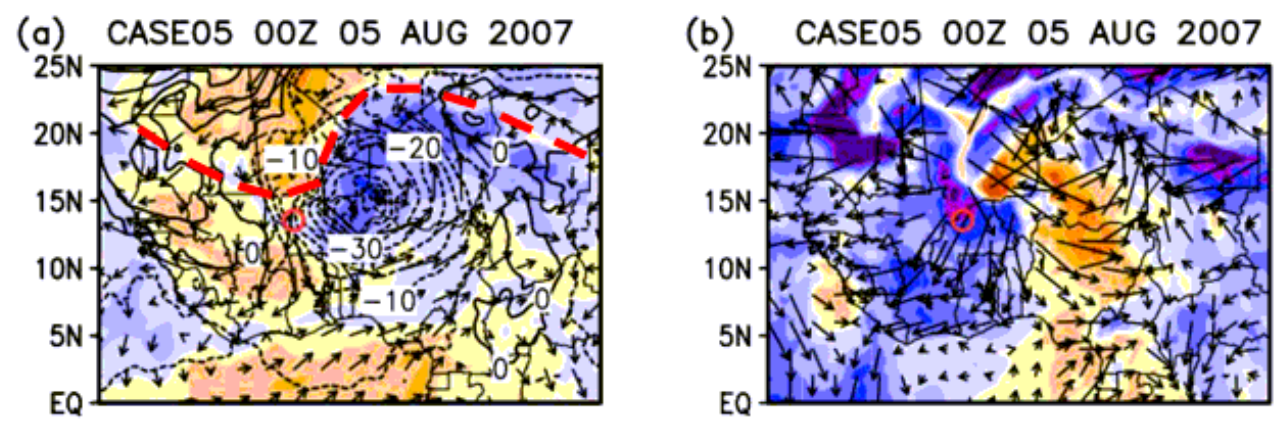

(c) CASE07 $00 Z 02$ SEP 2009
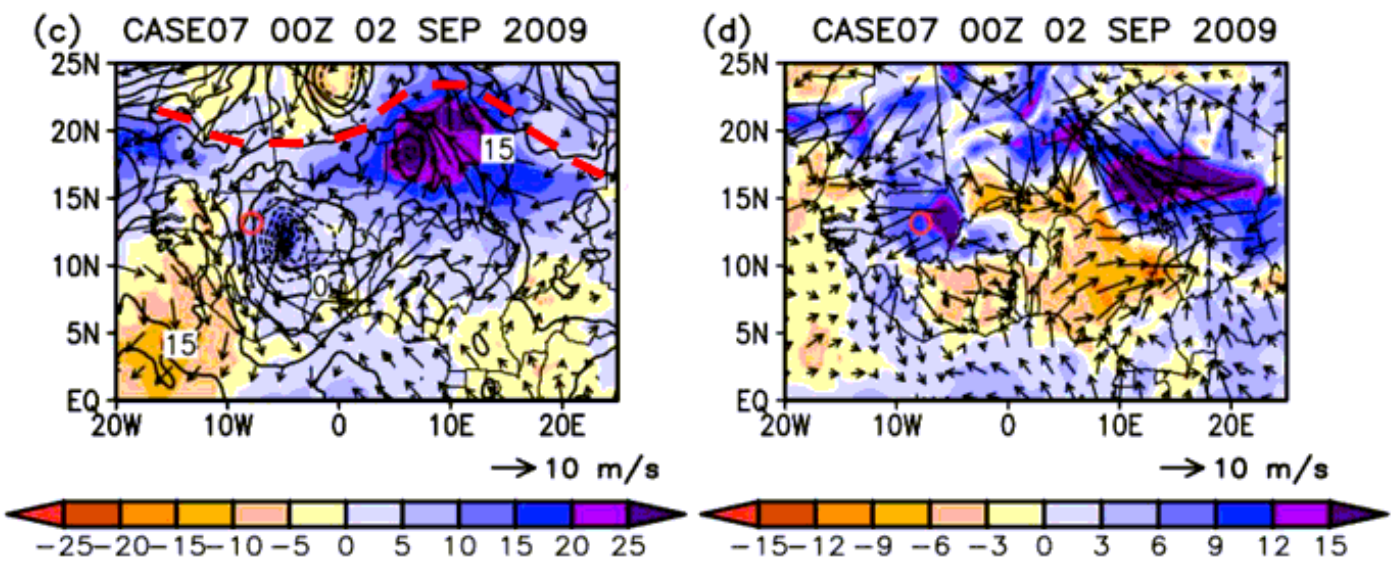

(e) CASE05 $700 \mathrm{hPa} \mathrm{RV}$

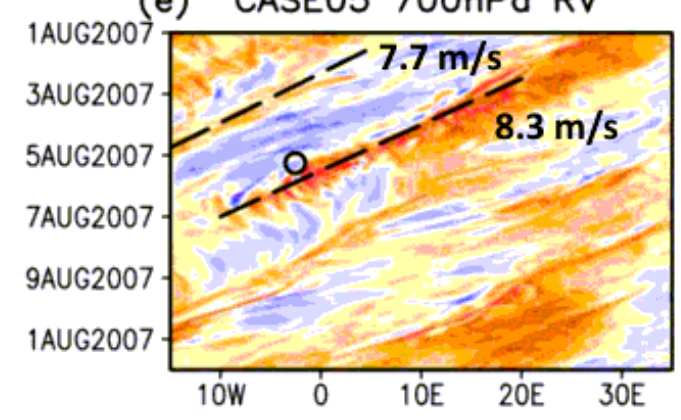

(g) CASE07 700hPa RV
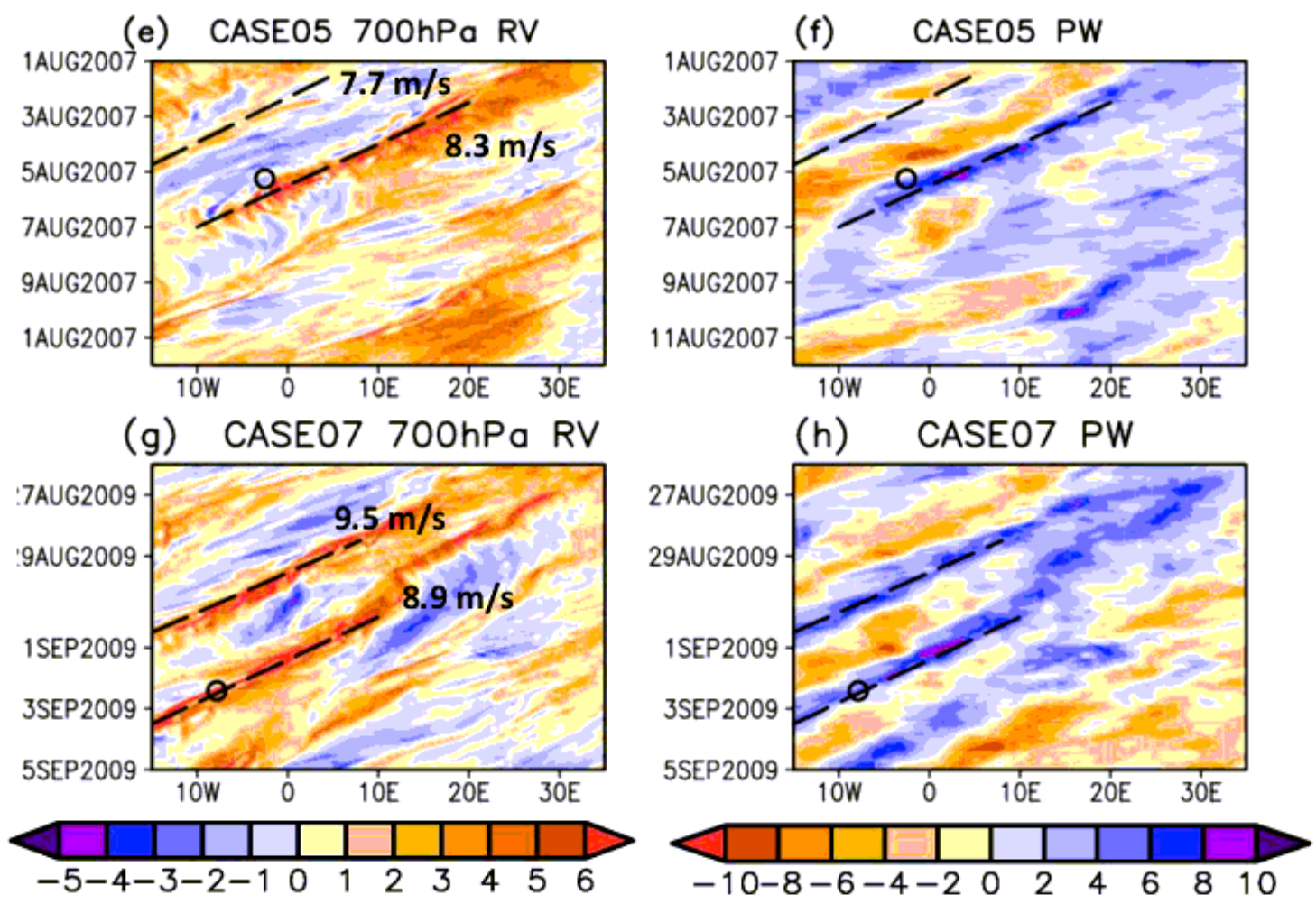

Figure 14

(a) $700 \mathrm{hPa}$ geopotential height (contours; m), $700 \mathrm{hPa}$ wind (vectors; $\mathrm{m} \mathrm{s}-1$ ), and precipitable water (shading; $\mathrm{mm}$ ) anomalies, and (b) $600 \mathrm{hPa}-925 \mathrm{hPa}$ horizontal wind difference (vectors; $\mathrm{m} \mathrm{s}-1$ ) and 
magnitude (shaded; m s-1) at a selected time for CASE05. (c) \& (d) similar, but for CASE07. Red circle denotes the location of the event maximum rainfall, while red dashed lined denotes position of the Sahel/tropical Africa dryline boundary. Hovmöllers of (e) $700 \mathrm{hPa}$ relative vorticity ( $\times 10-5 \mathrm{~s}-1)$ averaged from $10^{\circ} \mathrm{N}-15^{\circ} \mathrm{N}$, and (f) precipitable water differences from the 2000-2019 climatology $(\mathrm{mm})$ averaged from $10^{\circ} \mathrm{N}-15^{\circ} \mathrm{N}$ for CASE05. (g) \& (h) similar, but for CASE07. The circle denotes the time and longitude of the peak intensity of the event, while black dashed lines denote relevant wave disturbances and their estimated propagation speeds. 